\title{
Cell-Cell Junctions Organize Structural and Signaling Networks
}

\author{
Miguel A. Garcia, ${ }^{1}$ W. James Nelson, ${ }^{1,2}$ and Natalie Chavez ${ }^{1}$ \\ ${ }^{1}$ Department of Biology, Stanford University, Stanford, California 94305 \\ ${ }^{2}$ Departments of Molecular and Cellular Physiology, Stanford University, Stanford, California 94305 \\ Correspondence: wjnelson@stanford.edu
}

Cell-cell junctions link cells to each other in tissues, and regulate tissue homeostasis in critical cell processes that include tissue barrier function, cell proliferation, and migration. Defects in cell-cell junctions give rise to a wide range of tissue abnormalities that disrupt homeostasis and are common in genetic abnormalities and cancers. Here, we discuss the organization and function of cell-cell junctions primarily involved in adhesion (tight junction, adherens junction, and desmosomes) in two different epithelial tissues: a simple epithelium (intestine) and a stratified epithelium (epidermis). Studies in these tissues reveal similarities and differences in the organization and functions of different cell-cell junctions that meet the requirements for the specialized functions of each tissue. We discuss cell-cell junction responses to genetic and environmental perturbations that provide further insights into their roles in maintaining tissue homeostasis.

\section{Overview of Epithelial Tissue Organization}

Epithelia are evolutionary conserved and Eubiquitous in multicellular organisms. They form a continuous sheet of tightly linked cells that line the external-facing surfaces of organs and tissues, forming a barrier between the internal and external environments. The harsh conditions at this interface require that the epithelium is structurally robust and maintains a barrier to the outside environment. These properties are mediated by different types of cell-cell junctions that link epithelial cells together into a structural and functional continuum. Abnormalities in the organization of these junctions are common in genetic and metabolic disorders of epithelia. Here, we focus on the role of cellcell junctions in maintaining homeostasis in a simple epithelium (the intestinal epithelium) and a stratified epithelium (the skin epidermis).
The intestinal epithelium is lined by a single layer of cells that have a columnar shape that maximizes surface area for nutrient absorption and maintenance of a barrier to the outside environment (Helander and Fandriks 2014). The skin epithelium is organized in stratified cell layers to maximize the structural barrier, response to wounding and to minimize water loss (Furuse et al. 2002). Figure 1A illustrates the tissue architecture of the intestinal and skin epithelia. We focus on junctions involved in cell-cell adhesion and the differences in their roles in regulating tissue homeostasis. The reader is referred to specialized reviews on the development of the intestinal epithelium and skin epidermis (de Santa Barbara et al. 2003; van de Flier and Clevers 2009; Noah et al. 2011; Lu et al. 2013; Kulukian and Fuchs 2013; Hsu et al. 2014; see also, Buckley and Turner 2017 and Niessen 2017), and gap junctions

Editors: Carien M. Niessen and Alpha S. Yap

Additional Perspectives on Cell-Cell Junctions available at www.cshperspectives.org

Copyright (C) 2018 Cold Spring Harbor Laboratory Press; all rights reserved; doi: 10.1101/cshperspect.a029181

Cite this article as Cold Spring Harb Perspect Biol 2018;10:a029181 
M.A. Garcia et al.

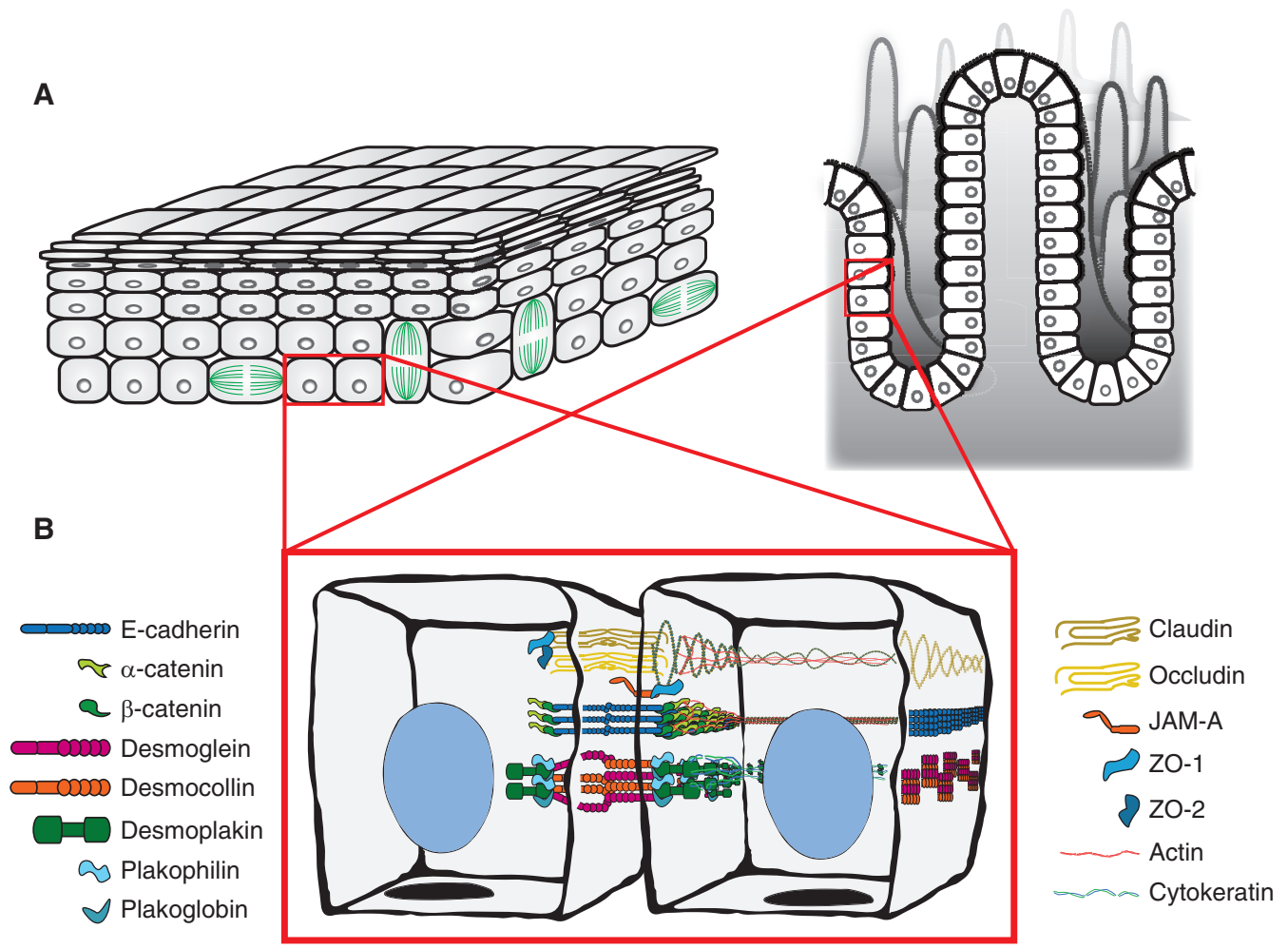

Figure 1. Tissue organization and cell junction composition in two different epithelia (intestine and epidermis). (A) The epidermis (left) is organized as stratified epithelium, and the intestine (right) is organized as a simple epithelium (one cell layer thick). (B) Composition and spatial organization of adhesive cell-cell junctions in epithelial cells. The tight junction (TJ) is localized to the most apical region of the cell and is composed of transmembrane proteins (claudin, occludin) and adaptor proteins (ZO-1 and ZO-2), which link to the underlying actin cytoskeleton. The adherens junction $(\mathrm{AJ})$ is localized on the lateral membrane and is primarily composed of the transmembrane protein, E-cadherin, and adaptor proteins, $\beta$-catenin and $\alpha$-catenin, which link to the underlying actin cytoskeleton. The desmosome (only one is shown, but many are located along the lateral membrane) is composed of transmembrane proteins (desmocollin and desmoglein) and adaptor proteins (plakoglobin, plakophillin, and desmoplakin), which links to cytokeratin intermediate filaments.

which are not discussed here (Willecke et al. 2002; Goodenough and Paul 2009; Maes et al. 2015).

\section{Overview of Epithelial Cell-Cell Junctions}

The intestinal epithelium and skin epidermis have a similar complement of cell-cell junctions that includes the tight junction, adherens junction, and desmosomes (Fig. 1B). These cell-cell junctions form extracellular connections between adjacent cells and intracellular connections with different elements of the cytoskeleton that together generate an integrated, structural continuum across the tissue. These junctions maintain homeostasis by regulating the structural integrity of the tissues, the diffusion of ions, solutes, and microbes across the tissue, cell proliferation, and cell migration. Molecular alterations in these junctions caused by genetic mutations and environmental perturbations provide further insights into junction structure and function in tissue homeostasis.

\section{Tight Junction}

In mammals, the tight junction (TJ) is located at the apex of the lateral plasma membranes 
between adhering cells. The TJ encircles each cell, forming a proteinaceous seal that regulates the diffusion of ions and solutes between cells (the paracellular pathway). The TJ provides a "fence" and "gate" barrier. The "fence" maintains the segregation of apical and basolateral membrane proteins and lipids (Zihni et al. 2016), and the "gate" is responsible for regulating the paracellular pathway.

The TJ is composed of two families of transmembrane proteins, claudin and occludin (Van Itallie and Anderson 2014), which form homotypic claudin-claudin and occludin-occludin complexes between cells. Claudins expressed in the human small intestine include claudin 1, 2, 3, 4, 5, 7, 8, 12, and 15 (Szakál et al. 2010; Sapone et al. 2011; Lameris et al. 2013; Lu et al. 2013). Claudins expressed in the epidermis include claudin 1, 4, and 7 (Kirschner and Brandner 2012). Linear clusters of claudins form characteristic TJ strands observed by freeze fracture electron microscopy (Furuse et al. 1998). The mutual assembly of TJ strands between attached cells generates a complex network of gaps or pores through which different ions and solutes are thought to diffuse (Gonzalez-Mariscal et al. 1985; Furuse et al. 1998, 2001; Van Itallie and Anderson 2006; Zihni et al. 2016). Different amino acids in the extracellular loops of claudins specify the permeability of ions of different size and charge, and hence diffusion in the paracellular pathway varies with the claudin types expressed (Van Itallie and Anderson 2006). However, it remains unclear how the TJ strand network is organized, and whether or how strands open and close to regulate paracellular flux.

The TJ function of occludin is less clear as occludin-null mice are viable with functional TJs and with no noticeable defects to intestinal epithelial barrier integrity (Saitou et al. 1998; Saitou et al. 2000). However, occludin may regulate the flux of large macromolecules across the intestinal TJ barrier (Al-Sadi et al. 2011).

Claudin and occludin bind directly to cytoplasmic adaptor proteins that in turn bind to the actin cytoskeleton (Umeda et al. 2004; Van Itallie et al. 2009; Fanning et al. 2012). These adaptor proteins comprise a family of PSD- 95/discs-large/zonula occludens-1 (PDZ) domain proteins $(\mathrm{ZO}-1,-2,-3)$, cingulin and additional proteins (Zihni et al. 2016). Zonula occludens $(\mathrm{ZO})$ proteins contain multifunctional domains that interact with claudins (PDZ1), occludin (U5+GUK), each other (PDZ2), and other signaling molecules (Fanning and Anderson 2009). These interactions are critical to life, as a deficiency in either ZO-1 or ZO-2 results in embryonic lethality (Katsuno et al. 2008; Xu et al. 2008). The PDZ1 domain of ZO-1 is required for the proper organization of the $\mathrm{TJ}$ and associated cytoskeleton (Rodgers et al. 2013). Other ZO-1 domains, including the SH3 domain/U5 motif and PDZ2, are required for proper $\mathrm{ZO}-1$ localization to the apical junction complex, and to establish normal permeability through the recruitment of a continuous circumferential band of other TJ proteins (Rodgers et al. 2013). Actin turnover and actomyosin contraction at the $\mathrm{TJ}$ also regulate $\mathrm{TJ}$ barrier function (Shen et al. 2006). Additionally, microtubules associate with TJs through cingulin (Yano et al. 2013).

The $\mathrm{TJ}$ also plays a role in regulating cell proliferation. ZO-1 and ZO-2 bind to the transcription factor ZO-1-associated nucleic acid binding protein (ZONAB) in a cell-density-dependent manner. ZONAB target genes include proliferative cell nuclear antigen (PCNA) and cyclin D1, which control cell proliferation (Balda et al. 2003; Sourisseau et al. 2006; Tsapara et al. 2006; Gonzalez-Mariscal et al. 2014). Depletion of ZO-1 and ZO-2 results in loss of ZONAB from the TJ and its degradation (Spadaro et al. 2014). The PDZ1 domain of ZO-2 also binds to another transcription factor, Yesassociated-protein (YAP), and facilitates YAP shuttling from the cytoplasm into the nucleus (Oka et al. 2010; Spadaro et al. 2014). The ZO2-YAP interaction may induce a proapoptotic or procell growth response depending on the physiological context (Oka et al. 2010; Dominguez-Calderon et al. 2016). ZO-3 also interacts with the PDZ binding domain of cyclin D1 to promote $S$ phase transition (Capaldo et al. 2011). Thus, $\mathrm{ZO}$ proteins regulate both barrier function and cell proliferation through interactions with different proteins at the TJ. 
M.A. Garcia et al.

ZO-1 binds to adherens junction (AJ) proteins $\alpha$-catenin and afadin (Itoh et al. 1997; Yamamoto et al. 1997; Muller et al. 2005). Additional PDZ-containing proteins interact with one another and have roles in linking complexes between the TJ and AJ. For example, PATJ is a multi-PDZ domain protein crucial for epithelial cell polarity, which acts as a link between apical and lateral compartments through its stabilization of AJ and its role in TJ assembly (Bhat et al. 1999; Bilder et al. 2003; Michel et al. 2005).

Junctional adhesion molecule (JAM) is a member of the immunoglobulin superfamily (JAM-A, -B, and -C) (Ebnet et al. 2004). JAM proteins localize to apical cell-cell contacts and interact with proteins of the $\mathrm{TJ}$ and $\mathrm{AJ}$ to regulate barrier function, cell migration, and cell proliferation (Laukoetter et al. 2007; Severson et al. 2009; Nava et al. 2011; Monteiro et al. 2013).

\section{Adherens Junction}

The adherens junction (AJ) initiates and maintains cell-cell adhesion, regulates the organization of the underlying actin cytoskeleton, and establishes a hub for cell signaling and regulation of gene transcription (Takeichi 2014). Classical cadherins, such as E-cadherin, are the main type of transmembrane protein comprising the $\mathrm{AJ}$ and contain five extracellular cadherin repeat domains that engage in $\mathrm{Ca}^{2+}$-dependent trans binding to a cadherin on the opposing cell surface (Shapiro and Weis 2009).

The cytoplasmic domain of E-cadherin forms a ternary complex with $\beta$-catenin, a member of the Armadillo family of proteins, and $\alpha$-catenin; in turn $\alpha$-catenin binds to F-actin in a force-dependent manner (Buckley et al. 2014). This cadherin-catenin complex also associates with microtubules (Ligon et al. 2001; Franz and Ridley 2004; Meng et al. 2008; Shahbazi et al. 2013). p120-Catenin also binds to the cadherin ternary complex, and regulates E-cadherin lifetime on the plasma membrane (Yap et al. 1998; Ireton et al. 2002; Davis et al. 2003). E-cadherin adhesion is strengthened through the recruitment of the mechanosensitive protein vinculin (le Duc et al. 2010; Huveneers et al.
2012; Thomas et al. 2013), which binds to a force-dependent conformation of $\alpha$-catenin (Yonemura et al. 2010; le Duc et al. 2010; Yao et al. 2014). Mechanical force links the E-cadherin ternary complex to the actin cytoskeleton and strengthens adhesion between cells, which emphasizes the importance of the mechanical environment of tissues in regulating the structure and function of cell-cell junctions.

Nectin, an immunoglobulin-like adhesion molecule, forms $\mathrm{Ca}^{2+}$-independent cell-cell adhesions at the AJ (Takai and Nakanishi 2003). Nectins bind afadin, which also binds $\alpha$-catenin (Pokutta et al. 2002; Weis and Nelson 2006) and ZO-1 (Yamamoto et al. 1997), which link nectin-based complexes to the actin cytoskeleton. Nectin-based adhesions may form first on cell-cell interfaces and in turn cooperate in the formation of the AJ through recruitment of the cadherin-catenin complex to nectin-based adhesions (Tachibana et al. 2000; Honda et al. 2003). This is an example of how junctional proteins work sequentially to regulate the transition from nascent to mature cell-cell contacts.

\section{Desmosomes}

Desmosomes comprise transmembrane cadherins of two subtypes, desmoglein (Dsg) and desmocollin (Dsc). Similar to classical cadherins, Dsg and Dsc contain five extracellular cadherin repeat domains that form both cis and trans interactions between opposing cells (Kowalczyk and Green 2013). The fundamental trans adhesive unit are $\mathrm{Ca}^{2+}$-dependent hetero(Dsg:Dsc) and homo- (Dsc:Dsc) dimers (Lowndes et al. 2014; Harrison et al. 2016), but a transition to a $\mathrm{Ca}^{2+}$-independent Dsg2:Dsc2 heterodimer occurs in very dense cells (Lowndes et al. 2014), which confers even stronger intercellular adhesion in the skin epidermis (Kimura et al. 2007; Tariq et al. 2015).

Dsg and Dsc interact with two members of the Armadillo family of proteins, plakoglobin and plakophilin (Broussard et al. 2015). Plakoglobin binds directly to Dsg and Dsc, and is required for desmosome assembly by clustering Dsg/Dsc in the plasma membrane; plakoglobin can also substitute for $\beta$-catenin in the AJ 
(Lewis et al. 1997; Kowalczyk et al. 1997; Bierkamp et al. 1999; Bornslaeger et al. 2001; Acehan et al. 2008). Plakoglobin in turn binds a member of the plakin family, desmoplakin, which binds directly to cytokeratin intermediate filaments (Hudson et al. 2004). Plakophilin is required for kinesin-2-dependent recruitment of Dsc2 to the plasma membrane (Nekrasova et al. 2011), and forms a scaffolding complex containing desmoplakin and protein kinase $C-\alpha$, which regulates the strength of interactions between desmoplakin and intermediate filaments to facilitate junctional integrity (Bass-Zubek et al. 2008; Nekrasova et al. 2011).

\section{INTESTINAL EPITHELIA ORGANIZATION AND REGULATION OF HOMEOSTASIS}

The intestinal epithelium forms the largest mucosal surface in the body with a total surface area of about $30 \mathrm{~m}^{2}$ in the adult human, which is approximately half the size of a badminton court (Helander and Fandriks 2014). The intestinal epithelium is organized to maximize surface area and absorptive potential, forming folds at the organ scale, tubular invaginations (crypts) and projections (villi) at the multicellular scale, and apical membrane projections (microvilli, also termed the brush border) at the subcellular level. The main functions of the small intestine epithelium are the digestion and absorption of nutrients from intraluminal food, and as a barrier to pathogens.

The intestinal epithelium comprises different cell types with specific functions that maintain intestinal epithelial homeostasis. Intestinal epithelial stem cells, located at the base of the crypts, divide continuously to give rise to the entire population of epithelial cells (enterocytes) (Al-Nafussi and Wright 1982; Schmidt et al. 1988). Paneth cells, which are also located in the crypts, and Goblet cells located in the villus, secrete mucin and antimicrobial substances that form a protective coat on the external epithelial surface. Enterocytes, which comprise $80 \%$ of the cells in the small intestine (van der Flier and Clevers 2009), are localized along the villus and are involved in active transepithelial movement of nutrients from the lumen to the serosa
(Lodish et al. 2000). Enteroendocrine cells are also located in the villus and assist in digestion through regulated secretion of hormones.

\section{Cell-Cell Junctions Establish and Maintain} Intestinal Epithelia Homeostasis

Here, we focus on the roles of the TJ and AJ in establishing and maintaining intestinal tissue homeostasis through regulation of barrier function, cell proliferation, and cell migration. Other junctional protein complexes (gap junctions, desmosomes) have not been studied extensively in the intestine, although some limited studies indicate important functions: loss of gap junction connexin- 43 expression caused acute ulceration and intestinal inflammation (Ey et al. 2009; Sedhom et al. 2013), and loss of connexin-32 was associated with increased tumor formation in the small intestine of mice (King et al. 2005). Other studies of desmosomes indicate that deletion of desmoplakin had no observable effect on cell-cell adhesion or tissue integrity (Sumigray and Lechler 2012). These limited studies indicate that further analysis of gap junctions and desmosomes could be informative.

\section{The Permeability Barrier and TJ Function}

The intestinal epithelium, which is only one cell layer thick, forms a barrier between the outside environment (the lumen of the gut) and the interior of the body (the serosa). At the whole tissue level, the barrier function is established by mucins and antimicrobial proteins secreted by Goblet and Paneth cells that block access of bacteria and viruses to the epithelial surface. Goblet cells also engage the immune system to defend against pathogen entry by transporting bacterial antigens across the intestinal barrier to immune cells beneath the epithelial layer (Peterson and Artis 2014). It is important to note that many bacteria are not pathogens, and that commensal bacteria enhance the barrier integrity of intestinal epithelia through Toll-like receptor 2 signaling (Cario et al. 2004).

At the cellular level, the barrier function is regulated by the TJ (Fig. $2 \mathrm{~A}$ ). TJ organization and function are regulated by the phosphoryla- 
M.A. Garcia et al.
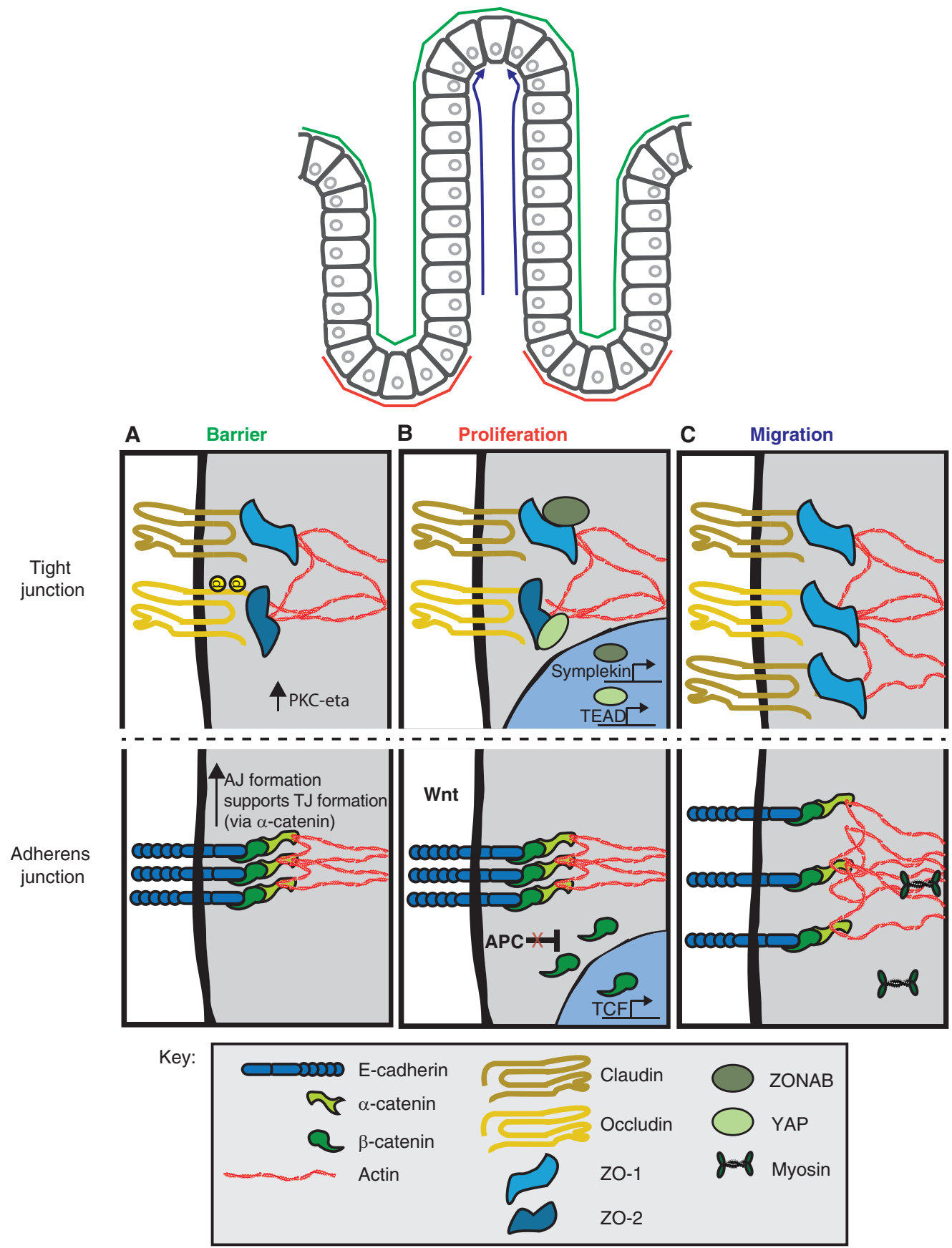

Figure 2. Cell-cell junction regulation of intestinal epithelial homeostasis. (A) Barrier function is primarily regulated by the tight junction (TJ) with indirect contributions by the adherens junction (AJ) through its role in TJ assembly. Phosphorylation of occludin by PKC- $\zeta$ results in occludin incorporation at the TJ. Phosphorylation of claudin results in its incorporation or removal from the TJ depending on the claudin type. $(B)$ Proliferation is dually regulated by the TJ and $\mathrm{AJ}$, which sequester proproliferation transcription factors, $\mathrm{ZO}-1$-associated nucleic acid binding protein (ZONAB), $\beta$-catenin and Yes-associated-protein (YAP). $(C)$ Cell migration is primarily mediated by alterations to components of the AJ, whereas changes in TJ protein homeostasis also occur. See text for details. 
tion status of occludin, claudins, and ZO-1. The highly conserved carboxy-terminal motif in occludin $\left({ }^{398}\right.$ YETDYTT $\left.^{404}\right)$ is heavily phosphorylated and a target for regulation of barrier function. Phosphorylation of Tyr398 and Tyr402 by Src kinase prevents occludin binding to ZO-1, resulting in the destabilization of occludin assembly at the TJ in Caco-2 intestinal epithelial cells in vitro, and colonic mucosa in vivo (Rao et al. 2002; Basuroy et al. 2005; Elias et al. 2009). Phosphorylation at T403 and T404 of occludin by PKC- $\eta$ is required for occludin localization to TJ (Suzuki et al. 2009). Inhibition of CK2-mediated S408 phosphorylation results in decreased paracellular cation flux, and reduction of occludin exchange at the membrane (Raleigh et al. 2011).

Phosphorylation of different claudin family members is associated with either increased or decreased TJ assembly and function. For example, PKA-mediated phosphorylation increases the assembly of claudin-3 at TJs, and, paradoxically, decreases the assembly of claudin-16 (D'Souza et al. 2005; Ikari et al. 2006). PP2A phosphatase activity results in decreased phosphorylation of claudin-1 resulting in increased detergent solubility of claudin-1, perhaps caused by decreased claudin-1 interaction with the actin cytoskeleton because PP2A also targets ZO-1 resulting in disruption of the interaction between ZO-1 and F-actin (Nunbhakdi-Craig et al. 2002). Tyrosine phosphorylation of ZO1 occurs during mechanical stimulation, but the amino acid residues that are tyrosine phosphorylated and the biological consequences of these phosphorylation events are unknown (Samak et al. 2014).

JAM proteins are not directly involved in TJ strand network formation, but nevertheless regulate epithelial paracellular permeability, cell migration and cell proliferation, in addition to immune cell recruitment during intestinal inflammation (Luissint et al. 2014). JAM proteins appear to play an indirect role in TJ strand formation because JAM-A depletion results in increased paracellular permeability and decreased transepithelial resistance (Martin-Padura et al. 1998; Furuse et al. 1998; Itoh et al. 2001; Laukoetter et al. 2007; Vetrano et al. 2008). JAM-A, which is expressed in mucosal cells, contains PDZ-binding domains and binds afadin (Monteiro et al. 2013), and afadin deletion phenocopied the JAM-A knockout in terms of a barrier defect and enhanced susceptibility to tissue injury (Laukoetter et al. 2007; TanakaOkamoto et al. 2011); afadin may be a downstream signaling molecule of JAM-A, perhaps through modulation of RhoA and actomyosin activities (Monteiro et al. 2013). Interestingly, JAM-A and the immune system compensate for each other in combating disease as JAM-A null mice have increased mucosal TGF- $\beta$ producing $\mathrm{CD} 4+\mathrm{T}$ helper cells and other leukocytes that provide a protective role of adaptive immunity in disease susceptible conditions (Khounlotham et al. 2012). Therefore, cell-cell junctions may not only play a critical structural role in establishing the barrier function, but may also facilitate cross talk with other cell types (i.e., immune system) to maintain homeostasis.

Interactions between the TJ and cytoskeleton are important in TJ barrier function, cell proliferation, and integrating the TJ with other junctions in the cell. Actomyosin contraction plays an important role in TJ formation, regulation of TJ dynamics, and TJ-mediated responses of cells to external stimuli (Rodgers and Fanning 2011; Lechuga et al. 2015). Generally, myosin light chain kinase (MLCK) activity, which activates myosin II, regulates barrier function by remodeling TJ structure, specifically through the redistribution of $\mathrm{ZO}-1$ and occludin as shown in Caco-2 intestinal cells in vitro (Shen et al. 2006). Changes of MLCK activity alter barrier function in intestinal cells in vivo under various biological and physiological contexts (Hecht et al. 1996; Turner et al. 1997; Zolotarevsky et al. 2002; Shen et al. 2006; Feighery et al. 2008; Samak et al. 2014; see Buckley and Turner 2017). Thus, cells generate internal forces through the contraction of the actomyosin network to alter the organization of the TJ and barrier function, that in turn regulate homeostasis in the presence of external challenges.

Disrupted TJ barrier function is found in inflammatory bowel syndrome (IBD), a prevalent gastrointestinal disorder characterized by chronic inflammation of the intestinal epithelia, 
M.A. Garcia et al.

and diarrhea (Barbara 2006). Many abnormalities in TJ protein organization and expression have been identified in IBD patients, in addition to alterations to immune system signaling (Fig. 3A) (Martinez et al. 2012a,b). However, it is unclear whether disrupted TJ barrier causes pathogenesis of IBD, or whether chronic inflammation results in the disruption of TJ function (Barbara 2006). Down-regulation of, and alterations in the subcellular localization of ZO1 have been observed in intestinal epithelia of IBD patients (Gassler et al. 2001; Poritz et al. 2007). Mislocalization of ZO-1 may be caused by the lack of claudin recruitment and formation of TJs, which ultimately results in barrier disruption (Umeda et al. 2006; Piche et al. 2009; Martinez et al. 2012). There is a correlation between activation of MLCK with inflammatory activity IBD (Blair et al. 2006; Cunningham and Turner 2012), and expression of constitutively active MLCK in the intestinal epithelia results in intestinal barrier loss (Su et al. 2009). MLCK has been linked to IBD, as discussed by Buckley and Turner (2017). Additionally, polymorphisms in the gene encoding Myosin9b have been identified in IBD patients; Myo9b is an actin-based molecular motor that plays key roles in facilitating epithelial wound repair and barrier integrity (Monsuur et al. 2005; van Bodegraven et al. 2006; Nunez et al. 2007; Cooney et al. 2009). Overexpression of mutant Myo9b in Caco-2 intestinal epithelial cells results in defects in wound closure caused by altered regulation of actin organization, and abnormal TJ formation caused by disruption of ZO-1 localization at the TJ (Chandhoke and Mooseker 2012).

Alterations in the barrier function of the mucosal lining have also been observed in inflammatory diseases of the intestine. Mucosal barrier defects result in increased numbers of immune-triggering antigens present in the mucosa, which in turn activate and amplify a response from the immune system that results in inflammation and disease (Barbara 2006; Dunlop et al. 2006). Additionally, defective mucosa barrier results in an overgrowth of bacterial colonies in patients with IBD (Lin 2004). Together, the disruption of the TJ and the mucosal lining in IBD act as a double loss of the cellular and biochemical barriers that maintain tissue integrity and protection from unwanted pathogens. Two therapeutic targets for IBD would be the prevention of intestinal inflammation and actomyosin contraction-induced disruption of the TJ.

Bacteria are thought to play a role in the inflammation and disease progression observed in IBD. Salmonella and Vibrio cholerae are two examples of pathogens that target the TJ to facilitate bacteria entry and cause disease (Guttman and Finlay 2009). Salmonella injects effector proteins into host cells, which decrease the expression of ZO-1, reduce levels of occludin at the TJ, and increase barrier permeability (Boyle et al. 2006; Kohler et al. 2007). V. cholerae uses the bacterial surface protein zonula occludens toxin (ZOT) to disrupt TJ function, specifically by causing the mislocalization of $\mathrm{ZO}-1$ and occludin, and increasing barrier permeability ( $\mathrm{Fa}-$ sano et al. 1995; Schmidt et al. 2007) perhaps through PKC $\alpha$ activity (Fasano et al. 1991). For more information regarding the relationship between bacteria, intestinal epithelia, and IBD the reader is referred to (Canny and McCormick 2008).

\section{AJ and TJ Involved in Cell Proliferation}

The entire gut epithelium in the adult human is renewed every 2 weeks (Al-Nafussi et al. 1982; Schmidt et al. 1988), which requires continual cell proliferation to repopulate the epithelium. Stem cells, located at the crypt of the villus, selfrenew, divide, and terminally differentiate into all the absorptive and secretory lineages (Barker 2014). Once the cells terminally differentiate, they migrate continuously to the top of the villus where they undergo apoptosis and are extruded from the epithelium into the intestinal lumen. Cell-cell junctions play indirect roles in regulating cell proliferation by sequestering specific transcription factors at the plasma membrane: ZO-1 and ZONAB (Balda et al. 2003), cadherins and $\beta$-catenin (Nelson and Nusse 2004), and ZO-2 and YAP1 (Oka et al. 2010; Spadaro et al. 2014). Figure 2B provides examples of the roles of each of these interactions, in addition to specific details below. 

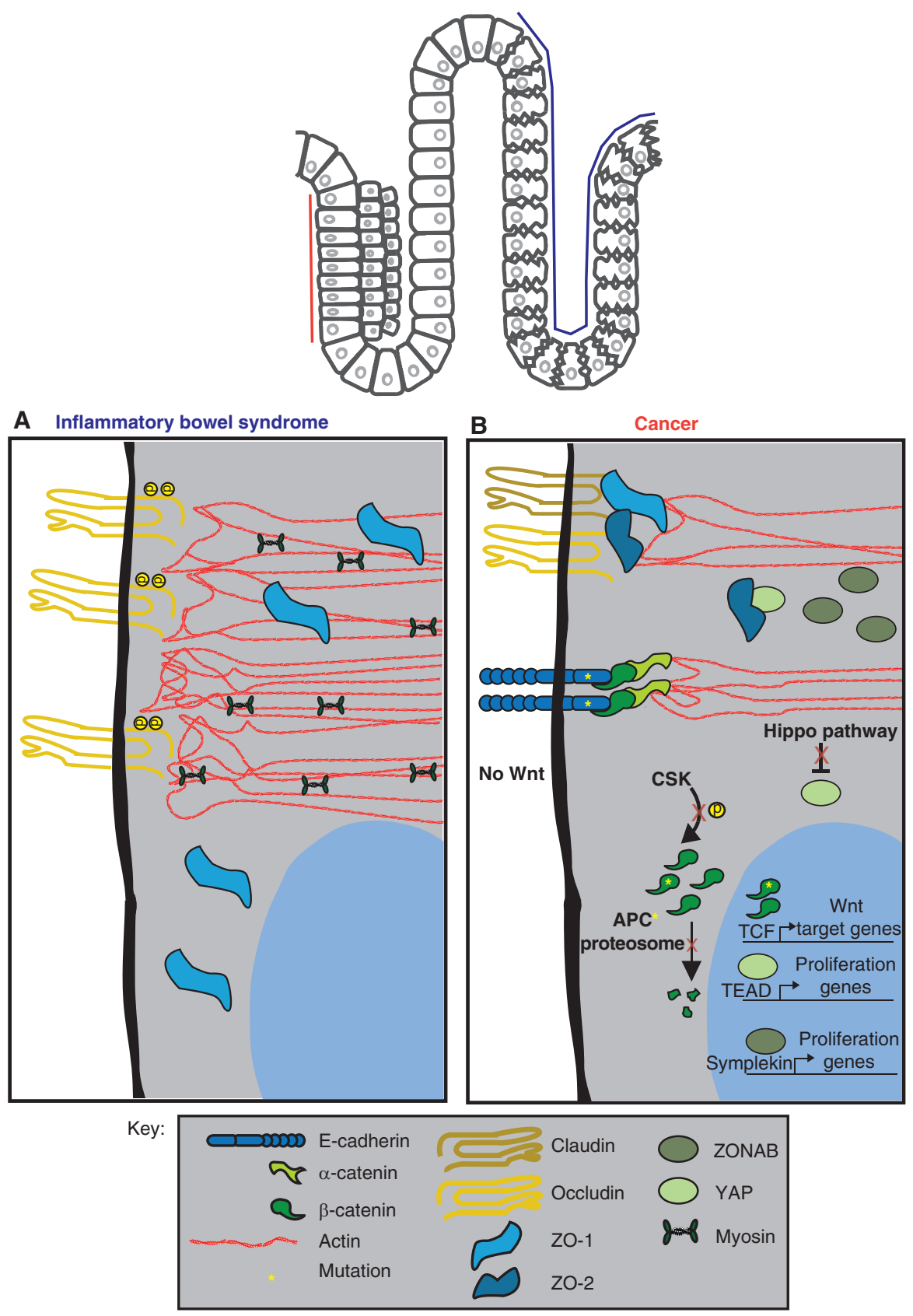

Figure 3. Disruption of homeostasis results in altered signaling at cell-cell junctions in intestinal epithelia. $(A)$ In inflammatory bowel disease (IBD), reduction or loss of ZO-1 and claudin-1 from the tight junction (TJ) has been observed, resulting in a loss of barrier function. A hyperactive actomyosin contractile network has also been reported. (B) In cancer, deregulated signaling at the TJ and adherens junction (AJ) occurs, resulting in uncontrolled proliferation mediated by $\beta$-catenin, Yes-associated-protein (YAP), and ZO-1-associated nucleic acid binding protein (ZONAB). Mutations in adenomatous polyposis coli (APC) and in $\beta$-catenin result in $\beta$-catenin accumulation by bypassing degradation in the absence of Wnt. Mutations in E-cadherin also result in cancer. See text for details. 
M.A. Garcia et al.

ZO-1 levels and TJ organization were disrupted, and $\mathrm{ZONAB}$ is translocated into the nucleus in intestinal cells treated with low levels of ethanol; nuclear translocation of ZONAB correlated with increased proliferation in the intestinal epithelium of ethanol-fed mice (Pannequin et al. 2007). Significantly, ZONAB has also been identified in the nucleus in adenomas of chronic alcoholics (Pannequin et al. 2007). Other studies in intestinal epithelial cells have shown that ZONAB expression is inversely correlated with differentiation, perhaps through the repression of the transcription factor Runxl/AML1 (Buchert et al. 2009). In summary, the TJ plays a role in regulating cell proliferation through its sequestration of ZONAB, and the TJ may be targeted for disruption to activate cell proliferation.

AJ proteins also regulate cell proliferation through Wnt signaling in the intestinal crypt (Fig. 2B). $\beta$-catenin is a transcription factor and critical downstream effector in the Wnt signaling pathway (Nelson and Nusse 2004). Mutations in different components of the Wnt pathway are common in intestinal cancers (Fig. 3B). For example, germ line mutations in the APC gene, a component of the $\beta$-catenin destruction complex, occur in a family of hereditary intestinal cancers termed familial adenomatous polyposis (Kinzler et al. 1991; Nishisho et al. 1991). These patients are heterozygous for APC mutations, and develop early onset colon polyps and adenomas in adulthood (Nishisho et al. 1991). Abnormal Wnt signaling is directly associated with uncontrolled proliferation in the intestine leading to the formation of adenomas and colorectal cancer (Kinzler and Vogelstein 1996; Vogelstein et al. 2013): 80\% of colorectal cancers are caused by mutations in APC that delete the $\beta$-catenin binding site on APC and therefore block targeting of $\beta$-catenin for degradation; the remaining $20 \%$ of colorectal cancers arise from mutations in $\beta$-catenin that block $\beta$-catenin phosphorylation by CKI/GSK3 and targeting to the destruction complex (Albuquerque et al. 2011; Kwong and Dove 2009). Genetic knockout of APC in mice leads to extraintestinal tumor formation (Sansom et al. 2004) caused by unregulated Wnt signaling (Andreu et al. 2005), and rapid colorectal ade- noma formation (Shibata et al. 1997). Therefore, mutations in either APC or $\beta$-catenin that inhibit $\beta$-catenin degradation in the absence of Wnt result in unregulated proliferation and disruption of homeostasis.

Mouse models have tested the role of $\beta$ catenin and cadherin in regulating cell proliferation in the intestine. An amino-terminal truncated $\beta$-catenin mutant, which lacks the CKI/GSK3 phosphorylation sites, accumulated in cells and induced small intestine polyps that phenocopied the effects of activation of Wnt signaling (Whitehead et al. 2008; Buchert et al. 2015); cell division and apoptosis also increased approximately fourfold in stem cells in the proliferative crypt compartment. Expression of a dominant negative $\mathrm{N}$-cadherin mutant lacking the cytoplasmic binding site for $\beta$-catenin in postmitotic enterocytes caused rapid and continuous cell migration up the small intestine villus, loss of the differentiated polarized phenotype of enterocytes, and precocious apoptosis (Hermiston and Gordon 1995).

E-cadherin mutations also cause gastrointestinal cancers. Hereditary gastric cancer is initiated as a result of a germ line mutation to the E-cadherin gene with an additional somatic down-regulation of the second E-cadherin allele by DNA promoter methylation (Humar and Guilford 2009). In vivo and in vitro studies have highlighted the importance of E-cadherin-based cell-cell adhesion in regulating critical homeostatic processes in the intestinal epithelium, such as the establishment of the brush border, crypt-villus migration, and cell proliferation (Hermiston and Gordon 1995; Hermiston et al. 1996). Mechanisms and regulation of these processes are discussed in detail in Buckley and Turner (2017).

Intestinal homeostasis is also regulated by the transcription factor YAP, which promotes cell proliferation and is negatively regulated by the Hippo pathway (Yu and Guan 2013). YAP activity promotes intestinal stem-cell expansion during normal growth and regeneration, and deregulation of the Hippo pathway results in colorectal cancer (Hong et al. 2016). Components of the AJ, including $\alpha$-catenin and E-cadherin, regulate the Hippo pathway by increasing 
the activity of Lats kinase, which suppresses YAP activation, or directly sequestering YAP at cellcell junctions (Yu and Guan 2013). Recently, a link between APC and the Hippo signaling pathway was shown in regulating cell proliferation. APC acts as a scaffold to components of the Hippo signaling pathway, Sav1 and Lats1, to regulate YAP-mediated cell proliferation in the mouse colon (Cai et al. 2015). Furthermore, YAP was shown to be required for the development of APC-deficient adenomas. This work establishes a second pathway, independent of the $\beta$-catenin destruction complex, by which APC regulates cell proliferation.

\section{Cell-Cell Junctions in Cell Migration}

Cell migration in the intestinal epithelium occurs continuously as stem cells divide in the crypt and daughter cells move up the villus, and apoptotic cells at the tip of the villus are sloughed off. This movement of cells from the crypt to the villus has been described as a "conveyer belt." As cells migrate to the top of the villus, E-cadherin, myosin II, Rho-associated kinase (ROCK), and MLCK are redistributed in cells (Fig. 2C) (Hopkins et al. 2007; Chen et al. 2014). In cells about to be extruded from the tip of the villus, ZO-1 and actin reorganize to form a "zipper" along the lateral membrane of live cells surrounding the apoptotic cell until the latter is completely extruded, and then the neighboring cells reestablish contact to reseal the epithelium (Madara 1990; Bullen et al. 2006; Guan et al. 2011; Marchiando et al. 2011; Williams et al. 2015 ). It is critical to maintain junctional integrity during cell migration and cell extrusion to prevent entry points to opportunistic pathogens that would disrupt homeostasis.

\section{EPIDERMIS ORGANIZATION AND REGULATION OF HOMEOSTASIS}

Cell-Cell Junctions Establish and Maintain Epidermal Homeostasis

The primary function of the skin epidermis is to provide a protective barrier against physical abrasions, pathogens, and the loss of water from underlying tissues and organs. The skin has an average surface area of $1.6-1.9 \mathrm{~m}^{2}$ in adult humans, approximately 12-20 distinct floral skin sites and an integrated sensory network that are critical for maintaining homeostasis (Sendroy and Cecchini 1954; Mosteller 1987; Boulais and Misery 2008; Grice and Segre 2011; Abraira and Ginty 2013; Findley et al. 2013).

The skin is comprised of two main layers, the dermis and the epidermis; here, we focus on the epidermis. The epidermis is comprised of four layers with many cell types and glands (Watt 2014). Embedded in the epidermis are melanocytes, immune cells, and sensory neurons that sense temperature, pressure, touch and pain (Abraira and Ginity 2013). The primary function of the epidermis is to form a barrier to the outside environment.

\section{TJ and Desmosomes in Barrier Function}

The epidermis is a permeability barrier to water loss from the interior. The TJ is the primary cell-cell junction that forms the barrier, although sebaceous glands also contribute a protective barrier of oils and antimicrobial lipids (Takigawa et al. 2005; Shi et al. 2015). The TJ is found in cells throughout the stratified epithelium, but canonical TJ strand networks are found only in the stratum granulosum (Brandner et al. 2002; Ohnemus et al. 2008).

The function of claudins in the epidermal barrier function is clear, because claudin- 1 deficient mice die within $1 \mathrm{~d}$ of birth because of massive dehydration (Fig. 4A) (Furuse et al. 2002). Inhibiting claudin-1 exocytosis also causes a defect in epidermal barrier function (Fig. 4A) (Youssef et al. 2013). Significantly, the overall morphology and integrity of the epidermis in claudin-1 knockout mice appeared normal, and other members of the claudin family were expressed. Thus, claudin-1 provides unique properties to the TJ that cannot be replaced by other claudins. Phosphorylation of claudins plays a role in TJ function, because phosphorylation of claudin-4 at S195 by atypical PKC is required to form a TJ in cultured keratinocytes (Aono and Hirai 2008). 

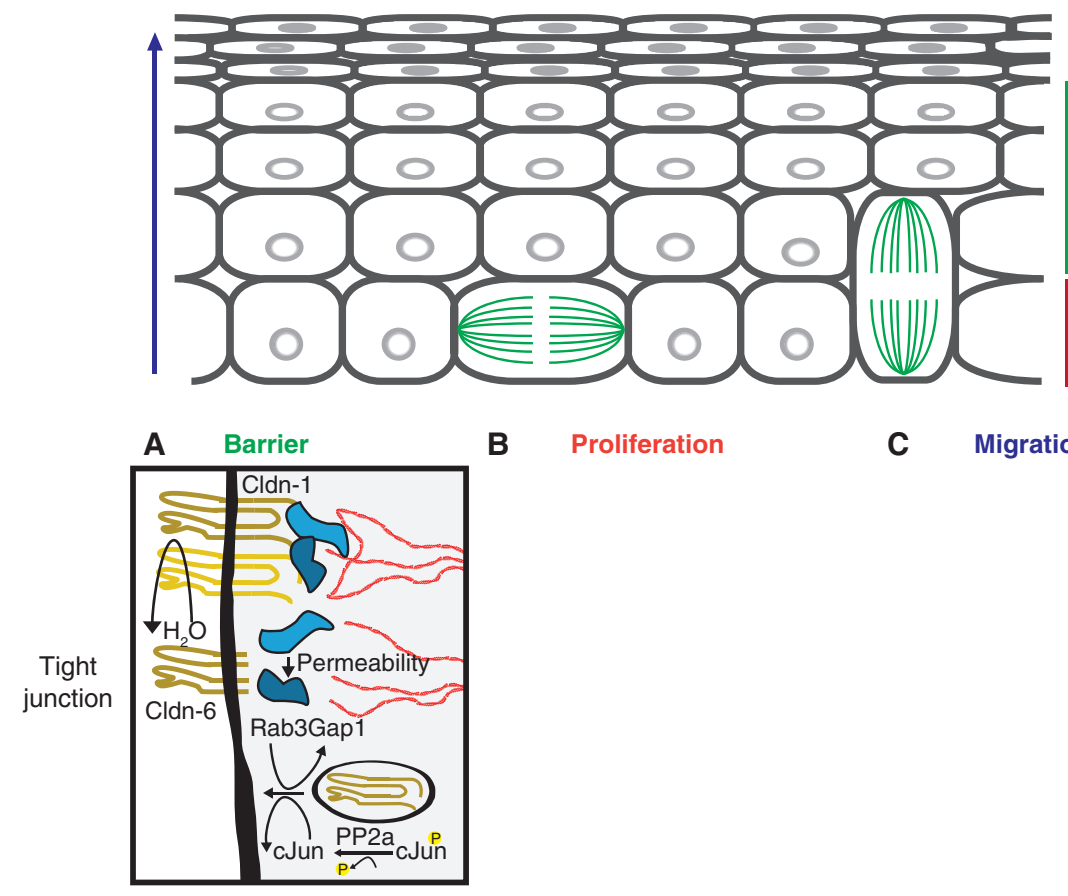

B Proliferation

C

Migration
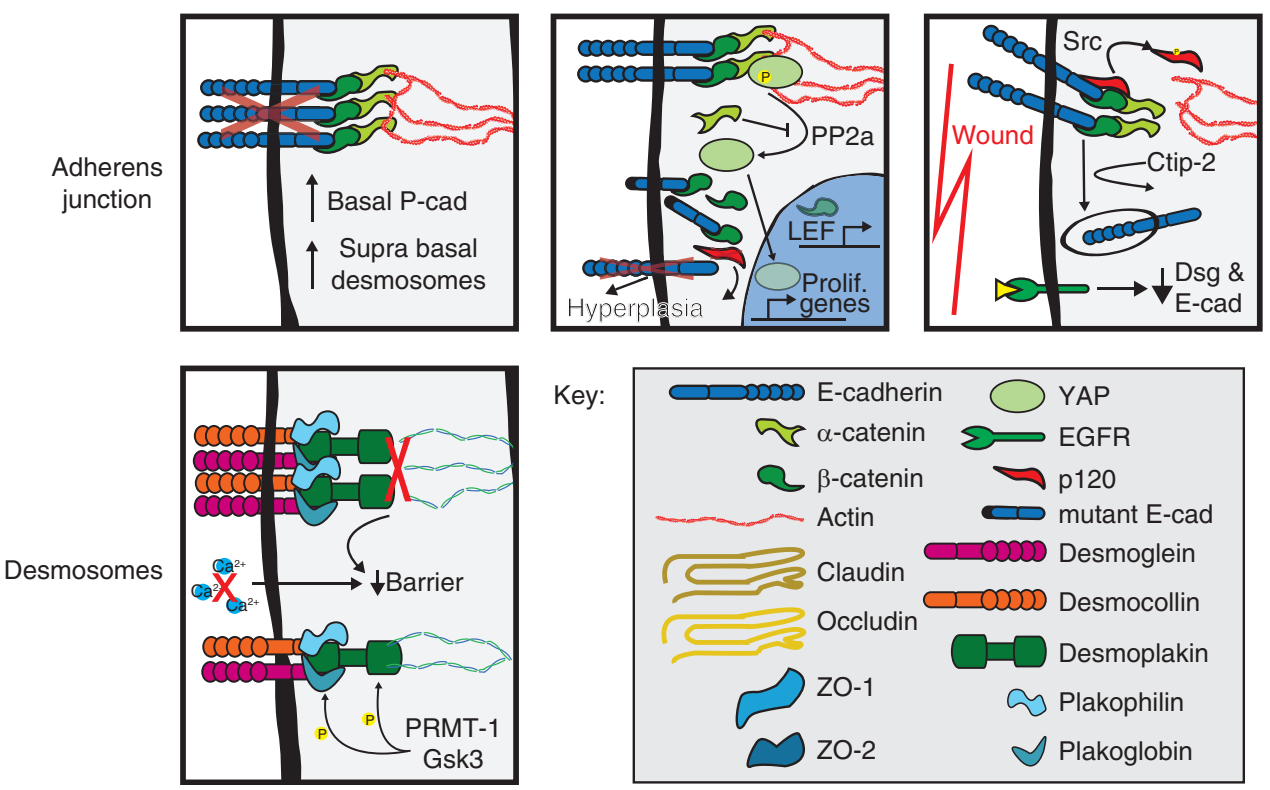

Figure 4. Cell junction regulation of homeostasis in epidermis. (A) Barrier function can be attributed to all junctional complexes. The tight junction (TJ) in the stratum granulosum prevent dehydration from the underlying tissues. Disruption of any claudin family member, particularly those that confer classic TJ strand organization, increases TJ and tissue permeability. At the adherens junctions (AJ), E-cadherin depletion results in a compensatory response by up-regulation of P-cadherin and desmosomes. Desmosomes are regulated by phosphorylation of desmosomal components, which is required for proper desmosome formation and cytokeratin association. Disruption in either the desmosome complex or cytokeratins leads to tissue lesions and blistering phenotypes. (B) Proliferation has been studied well with respect to AJ in the epidermis. The primary role Ecadherin in proliferation is to sequester transcription factors such as $\beta$-catenin from the nucleus. $(C)$ Cell migration is primarily studied in the context of wound healing. E-cadherin is down-regulated at wound edges, proceeded by desmosome down-regulation perhaps to increase migration or release sequestered signaling proteins. See text for details. 
The function of TJ adaptor proteins (ZO-1, $-2,-3)$ in the epidermis has not been studied directly. However, expression of a mutant claudin-6 lacking the carboxy-terminal binding domain for $\mathrm{ZO}$ proteins led to the disruption of barrier function and aberrant expression of differentiation markers (Fig. 4A) (Troy and Turksen 2007). Thus, binding of claudins to adaptor proteins and the actin cytoskeleton is important for maintaining epidermal TJ function.

The epidermis serves as a physical barrier that covers the body, and it must, therefore, have strong structural integrity. The primary structures that confer mechanical integrity to the epidermis are desmosomes, which are found in all layers of the epidermis except the stratum corneum. Members of the desmosomal cadherin family (Dsg, Dsc) are expressed throughout the stratified layers of the epidermis (Getsios et al. 2004; Nekrasova and Green 2013), but in different combinations. The differential expression of Dsg and Dsc family members may confer different adhesive strengths specific to different layers (Chidgey et al. 2001; Merritt et al. 2002; Garrod and Chidgey 2008). For example, in the presence of extracellular $\mathrm{Ca}^{2+}$, desmosomes form intercellular adhesions that are relatively weak, similar to AJ cadherins, but over time desmosomes become $\mathrm{Ca}^{2+}$-independent and form stronger adhesions (Kimura et al. 2007; Tariq et al. 2015). This hyperadhesion may be achieved by a transition from $\mathrm{Ca}^{2+}$-dependent Dsg:Dsg and Dsc:Dsc homodimers, to a $\mathrm{Ca}^{2+}$ independent Dsg2:Dsc2 heterodimer (Lowndes et al. 2014; Harrison et al. 2016).

Disruption of any part of the desmosomal complex leads to fragility, blistering and, in extreme cases, sloughing of the entire epidermis (reviewed in Kottke et al. 2006; Haines and Lane 2012; Broussard et al. 2015). The lesion site in the epidermis depends on which desmosomal cadherin is disrupted. For example, loss of Dsg3 adhesion, which is located in the stratum basale, in Pemphigus vulgaris patients results in detachment of the basal layers of the epidermis from the dermis, which can be lethal (Amagai et al. 1991; Koch et al. 1997). In Pemphigus vulgaris, autoimmune antibodies bind to the amino-terminal of the extracellular region of Dsg3 and cause desmosomes to undergo acantholysis, the loss of intercellular adhesion between desmosomal plaques, without cytokeratin retraction on the apical surface of basal keratinocytes (Fig. 5) (Shimizu et al. 2004; Yamamoto et al. 2007). Targeted disruption of Dsc1, which is primarily expressed in the suprabasal layers, led to barrier defects that are not as severe as that caused by Dsg3 disruption (Chidgey et al. 2001). Differences in the severity of the structural defect in the epidermis are caused by the locations of Dsc1 (more superficial layers) and Dsg3 (more basal layers).

Staphylococcus aureus and adenovirus target specific desmosomal cadherins resulting in disruption of epidermis integrity. S. aureus produces the serine proteases Exfoliative toxins A and $\mathrm{B}$, which bind to, and cleave the aminoterminal region of Dsg1 (Fig. 5) (Amagai et al. 1995; Sekiguchi et al. 2001; Bukowski et al. 2010), resulting in blistering just below the stratum corneum (staphylococcal scalded skin syndrome and bullous impetigo) (Amagai et al. 2000, 2002). In some serotypes of adenoviruses, the fiber knob domain of spike-like protrusions of the virus specifically target Dsg2 (Wang et al. 2011). Once bound, mitogen-activated protein (MAP) kinases activate the extracellular matrix metalloproteinase ADAM17, which cleaves the extracellular domain of Dsg2 (Fig. 5) (Wang et al. 2013, 2015); this process has been used as an ectopic procedure to increase the penetration of therapeutic drugs into the skin (Yumul et al. 2016).

Mutations in desmosomal-associated armadillo family adaptor proteins also result in defects in barrier function. Deletion of plakoglobin in mice results in skin blistering and peeling, and very early postnatal death (Bierkamp et al. 1996). A mutation in plakoglobin causes Naxos disease, an autosomal-recessive disorder involving heart, skin, and hair abnormalities (McKoy et al. 2000). Mutations in plakophilin 1 and 2 also disrupt desmosome assembly and stability resulting in skin fragility and blistering (McGrath et al. 1997; McGrath and Mellerio 2010; Hall 2009). Src inhibition prevented phosphorylation of plakophilin-3, which reduced the disruptive effects of Pemphigus vulgaris 
M.A. Garcia et al.
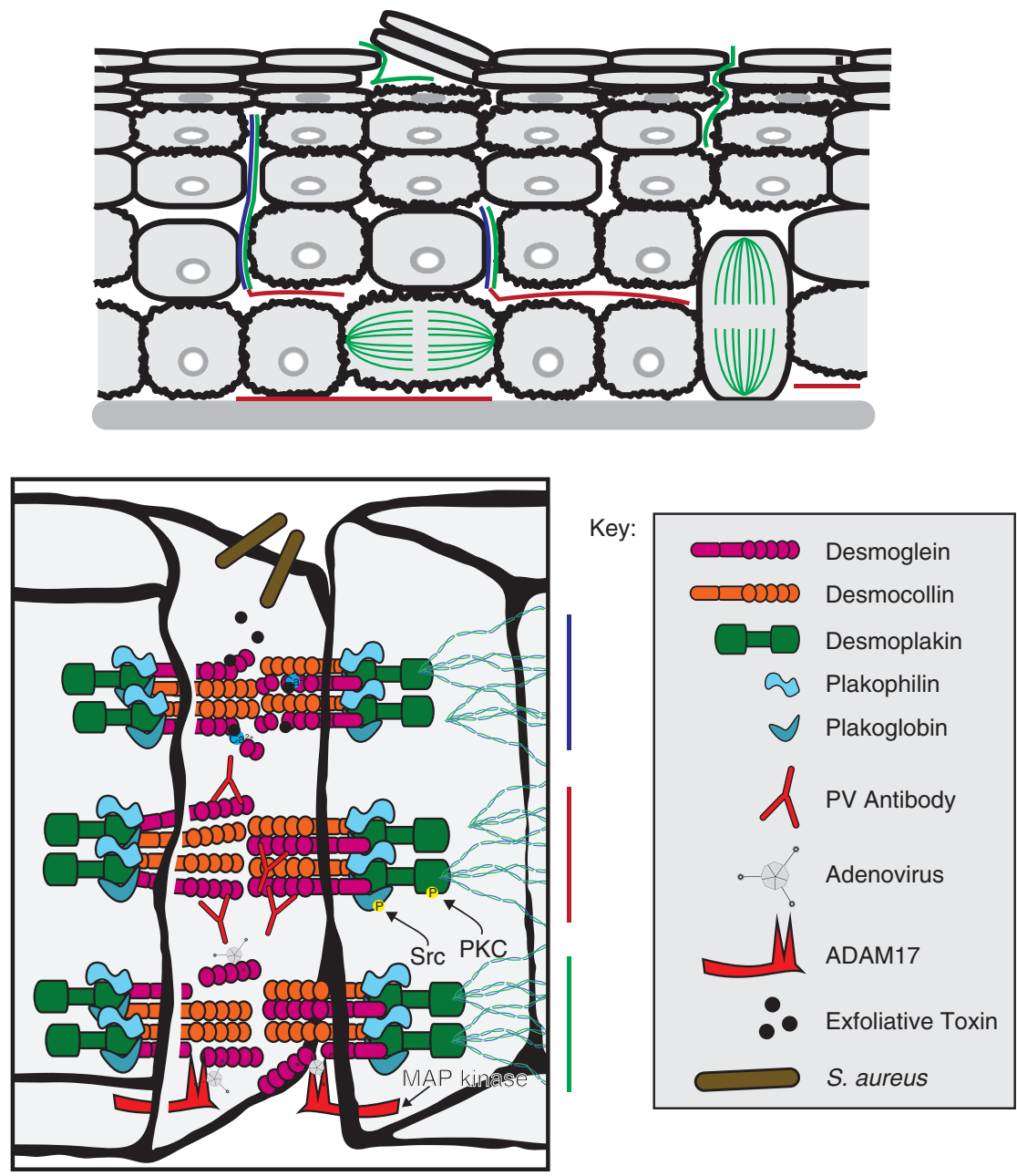

Figure 5. Disruption of cell junctions results in altered homeostasis in the epidermis. Desmoglein targeted for cleavage or disruption causes subcutaneous defects in the epidermis. Staphylococcus aureus releases exfoliative toxins that cleave Dsg1 at the EC2 domain. IgGs that recognize the amino-terminal domain of Dsg3 trigger phosphorylation of desmoplakin and plakophilin, which reduced cytokeratin association and decreased plaque integrity at desmosomes. Similar to exfoliative toxins, the fiber knob domain of adenovirus binds the extracellular region of Dsg3 resulting in activation of ADAM17, which cleaves the extracellular domain of Dsg3. See text for details.

autoimmune antibodies (Cirillo et al. 2014). Genetic loss of desmoplakin causes the loss of skin integrity caused by intercellular separation and loss of desmosomal linkages to the cytokeratin intermediate filaments (Vasioukhin et al. 2001b), and desmoplakin mutations have been found in cases of palmoplantar keratoderma, woolly hair syndrome, and cardiomyopathy (Pigors et al. 2015). Desmoplakin is phosphor- ylated in the presence of Pemphigus vulgaris autoimmune antibodies, which decreases cytokeratin intermediate filament binding to desmosomes (Fig. 5) (Dehner et al. 2014). Thus, all components of desmosomes are required to maintain normal function, and structural integrity of the epidermis.

The phosphorylation state of desmosome proteins also regulates the structure and func- 
tion of the complex. Introduction of a phosphorylation-deficient plakoglobin mutant into plakoglobin null keratinocytes prevented epidermal growth factor receptor (EGFR)-dependent loss of desmoplakin from junctions (Yin et al. 2005), indicating that plakoglobin regulates the assembly state of the desmosome complex. Phosphorylation of serine and arginine sites on desmoplakin by GSK3 and PRMT-1, respectively, regulate the association of desmoplakin with cytokeratins and the rate of desmosome assembly (Fig. 4A) (Albrecht et al. 2015). In contrast without keratins, PKC- $\alpha$-mediated desmoplakin phosphorylation decreases retention of desmosomes at cell-cell contacts (Kroger et al. 2013).

Cytokeratin intermediate filaments, which bind directly to desmoplakin, are a signature component of the epidermis, and different subtypes are characteristically expressed in different layers of the epidermis (Haines and Lane 2012; Loschke et al. 2015). Cytokeratins are composed of heterotypic dimers of Type I (acidic) and Type II (basic) keratins (Herrmann and Aebi 2004; Loschke et al. 2015). The effects of mutations, depletion or complete knockdown of cytokeratin genes have been studied extensively (reviewed in Chernyatina et al. 2015; Toivola et al. 2015). In general, epidermal homeostasis depends on keratin filaments bound to desmosomal junctions, and specific keratins can have significantly different functions. The four following examples illustrate this point, and the reader is referred to recent reviews of cytokeratins for additional examples (Haines and Lane 2012; Knobel et al. 2015): (1) Deletion of keratin 10 results in hyperproliferation in the basal layer of the epidermis, which led to an abnormal thickening of the suprabasal layers, termed hyperkeratosis (Reichelt and Magin 2002; Muller et al. 2006). (2) Deletion of keratin 14 results in intercellular separation of the epidermis and dermis at the basal layer; although desmosomal plaques remained they were not associated with cytokeratin filaments (Chan et al. 1994; Rugg et al. 1994). (3) Epidermolysis bullosa simplex is a disease that is primarily caused by a mutation in keratin 5 and 14 genes (Fine et al. 2014; Vahidnezhad et al. 2016). The mutation is usu- ally a dominant negative missense mutation most frequently in the keratin 14 gene (Coulombe and Lee 2012). The result is a separation in the skin at the dermoepidermal junction that can lead to infection and dehydration (Garcia Perez 1999; Kim et al. 2014). (4) Keratinocytes in which all cytokeratins were deleted had a $60 \%$ increase in deformability compared to normal cells (Ramms et al. 2013; Seltmann et al. 2013). Note that cells depleted of all keratins retained microtubule and actin networks, and normal appearing $\mathrm{AJ}$ and $\mathrm{TJ}$. A normal phenotype could be rescued by reexpression of keratins 5 and 14 (Vijayaraj et al. 2009; Ramms et al. 2013; Seltmann et al. 2013).

\section{The Roles of the AJ in Skin Homeostasis}

$\mathrm{The} \mathrm{Ca}^{2+}$-dependent, transmembrane adhesion protein E-cadherin is one of the most robustly expressed proteins in epithelia. In the epidermis, E-cadherin is expressed in all stratified layers and is responsible for initiating cell-cell contacts (Damsky et al. 1983). The contributions of Ecadherin to epidermal homeostasis are significant. Conditional knockouts of E-cadherin in the epidermis of mice resulted in thickening of the epidermis and defects in terminal differentiation as well as perinatal death due to improper tight junction formation (Tinkle et al. 2004; Tunggal et al. 2005); hyperplasia also developed in aging keratinocytes derived from E-cadherinknockout mice. Furthermore, loss of E-cadherin resulted in elevated levels of P-cadherin in the basal layer of keratinocytes, and increased expression of desmosomal cadherins in suprabasal keratinocytes; the weak compensatory function of P-cadherin and up-regulation of desmosomes contributed to the maintenance of some barrier function (Fig. 4B,C).

$\mathrm{P}$-cadherin is expressed in the basal layer of the epidermis (Hirai et al. 1989). Loss of P-cadherin led to hypotrichosis with juvenile macular dystrophy (HJMD) and ectodermal dysplasia, ectrodactyly, and macular dystrophy (EEM) syndromes (Singh et al. 2016). Loss of P-cadherin expression in mice lacking E-cadherin had no effect on cell proliferation (Tinkle et al. 2008), but intercellular adhesion was severely 
M.A. Garcia et al.

impaired to an extent resembling defects in $\alpha$ catenin-deficient skin (Vasioukhin et al. 2001a). Loss of $\alpha$-catenin expression in E-cadherin knockout mice caused an inflammatory cell infiltrate and enhanced epidermal NFкB activation (Kobielak and Fuchs 2006; Tinkle et al. 2008).

In keratinocytes, $\alpha$-catenin negatively regulates Yap1 activity by preventing its dephosphorylation (Fig. 4B). Dephosphorylated Yap1 can enter the nucleus and activate the Hippo pathway leading to cell proliferation. $\alpha$-catenin may modulate the interaction of Yap1 with 14-3-3 protein, thereby blocking Yap1 dephosphorylation by the phosphatase PP2A (Schlegelmilch et al. 2011). Loss of $\alpha$-catenin and p120-catenin expression in the skin led to a hyperactivation of MAPK and NFкB signaling and hyperplasia (Fig. 4B) (Kobielak and Fuchs 2006; Perez-Moreno et al. 2006; Vasioukhin et al. 2001a).

\section{A) Involved in Cell Proliferation}

Cells in the epidermis are constantly turning over, and must be replaced by cells derived from stem-cell populations (Fuchs 2016). Within the epidermis there are two populations of proliferative cells: committed progenitors comprising the stem cells of the stratum basale, and transit-amplifying cells comprising slow-cycling cells that undergo terminal differentiation after a number of cell divisions (Clayton et al. 2007; Mascre et al. 2012). Committed progenitor cells undergo asymmetric and symmetric divisions that contribute to the maintenance of the stratified epithelium and stem-cell populations (Lechler and Fuchs 2005). Studies of Eand $\mathrm{P}$-cadherin, and $\beta$-catenin have provided insight to the importance of the AJ in cell proliferation and differentiation.

In cultured keratinocytes, expression of a dominant negative E-cadherin mutant lacking the extracellular domain, which could still form complexes with $\alpha$ - $\beta$ - and $\gamma$-catenin, decreased the level of endogenoues cadherins and increased the level of cytosolic $\beta$-catenin (Fig. 4B) (Zhu and Watt 1996), which stimulated terminal differentiation. Normally, sequestration of $\beta$-catenin by binding cadherins negatively regulates $\beta$-catenin transcriptional activity (Orsulic et al. 1999; Niemann et al. 2002). Excess cytoplasmic $\beta$-catenin could be responsible for maintaining the proliferative potential of keratinocyte stem cells (Fig. 4B) (Zhu and Watt 1999). Interestingly, conditional expression of mutant $\beta$-catenin in the epidermis of mice resulted in the failure of stem-cell keratinocytes to differentiate into follicular cells, but instead they adopted an epidermal fate (Huelsken et al. 2001). Lymphoid enhancer-binding factor (LEF), which forms a transcription complex with $\beta$-catenin, regulates lineage differentiation in stem cells of the skin (Fig. 4B) (Merrill et al. 2001). Blocking $\beta$-catenin signaling with an amino-terminally truncated LEF1 caused hair follicles to transdifferentiate into interfollicular epidermis and sebocytes (Braun et al. 2003). Thus the balance between sequestration and release of $\beta$-catenin from E-cadherin is important in regulating cell proliferation and differentiation of stem cells in the skin.

\section{Cell-Cell Junctions in Cell Migration and Wound Healing}

Keratinocyte migration in response to wounding results in reepithelialization of the tissue. Canonically, two mechanisms-termed the rolling and treadmilling mechanisms - may be responsible for cell migration on wounding. The rolling mechanism involves suprabasal keratinocytes migrating over the basal keratinocytes and into the wound where they then dedifferentiate and form new layers (Krawczyk 1971; Paladini et al. 1996); studies in 3D keratinocyte cultures indicate a similar process, termed the extending shield mechanism (Safferling et al. 2013). The treadmilling mechanism involves basal keratinocytes migrated into the wound and then pulling the suprabasal cells behind them until wound closure (Radice 1980; Woodley et al. 1993). Both mechanisms could also combine to activate both basal and suprabasal keratinocytes in response to wounding (Usui et al. 2005; Safferling et al. 2013).

The AJ appears to play a significant role in wound healing. E-cadherin expression decreases close to the edge of a wound, potentially 
allowing cells to lose cell-cell adhesion, migrate and increase proliferation (Fig. 4C) (Kuwahara et al. 2001). The transcription factor COUP-TF interacting protein 2 (Ctip-2) is required for migration, and down-regulation of E-cadherin expression (Liang et al. 2012). Down-regulation of E-cadherin could also occur in part by Src phosphorylation of p120-catenin leading to internalization of E-cadherin during wound healing (Fig. 4C) (Huang et al. 2016). Also, activation of EGFR, which can phosphorylate the cadherin-catenin complex, disrupted junctional complexes and stimulated wound repair (Bhora et al. 1995; Hudson and McCawley 1998; Nanney et al. 2000; Repertinger et al. 2004). Furthermore, 48 hours after wounding EGFR activation down-regulates the expression of Dsg and E-cadherin through Rab 11-mediated Dsg recycling and E-cadherin cleavage (Fig. 4C) (Chavez et al. 2012).

The Hippo pathway effector proteins Taz and Yap, which interact with ZO-2 and $\alpha$-catenin (Kim et al. 2011; Schlegelmilch et al. 2011; Silvis et al. 2011), may also play a role in cell migration on wounding. Taz localizes to the nucleus $1 \mathrm{~d}$ after wound healing, whereas YAP localizes to the nucleus after 2-7 d; knockdown of both Yap and Taz expression resulted in a marked decrease in wound repair (Lee et al. 2014). These studies suggest that cell-cell junctional proteins and different signaling pathways that modify E-cadherin-mediated cell-cell adhesion are involved in inducing cell migration and proliferation.

\section{SIMILARITIES IN CELL-CELL JUNCTION FUNCTIONS IN MAINTAINING HOMEOSTASIS IN DIFFERENT EPITHELIA}

Both the intestinal epithelia and epidermis cover large surface areas of the body and have the primary role of serving as a protective barrier from the harsh external environment. Both epithelia are composed of biochemical and cellular barriers that exclude pathogenic microbes, while facilitating interactions with commensal microbes, which modulate and sometimes enhance barrier function, as in the intestinal epithelium. Additionally, both the intestinal epithelia and epidermis use cell-cell junctions to maintain homeostasis through regulating cell proliferation, migration, and the structural barrier. In general, cell-cell junctions are used in similar ways to maintain homeostasis in the intestinal epithelia and epidermis despite differences in the organization of the tissues.

The primary role of both the intestinal epithelia and epidermis is to serve as a protective barrier for the large surface area covered by each of these tissues. The intestinal epithelium is organized as a cell monolayer that is folded on multiple levels to maximize the surface area for nutrient reabsorption. The epidermis, in contrast, is organized in multiple strata of epithelial cells to withstand injury and mechanical stress. In both tissues, the TJ is located in cells immediately adjacent to the extracellular environment: the TJ is located at the apical region of intestinal epithelial cells, and the canonical TJ in the epidermis is located in the most external live cell layer (stratum granulosum). Claudin-1 is essential in both tissues for TJ formation and function. However, it does appear that the role of ZO-1 in regulating paracellular permeability has been more extensively studied in the intestinal epithelia compared to the epidermis, in which interactions between ZO-1 and claudins are critical for barrier function.

In both the intestinal epithelia and the epidermis, cell-cell junctions play a role in regulating cell proliferation in stem cells in the base of the crypt in the intestinal epithelium, and the basal layer of the skin epidermis. Wnt and Hippo pathways are important in controlling cell proliferation in both tissues, and both pathways are regulated by cell-cell junctions. $\beta$-catenin regulates cell proliferation and differentiation in both tissues. Additionally, mutations in $\beta$-catenin that prevent its degradation by the APC destruction complex result in cancer. YAP also plays a role in regulating proliferation in both tissues. Both $\beta$-catenin and YAP transcriptional activities are also regulated in part by sequestering them at the plasma membrane in $\mathrm{AJ}$ and $\mathrm{TJ}$ complexes.

Roles for the desmosome in the epidermis are clear, but less so for the intestinal epithelia. Desmosomes are responsible for maintaining 
M.A. Garcia et al.

mechanical integrity and barrier function of the epidermis, through the accumulation of plaque proteins and the organization of keratin intermediate filaments. Additionally, different layers of the epidermis express different types of Dsc and Dsg and keratins to perhaps tune the mechanical integrity of the epidermis at each layer. In contrast, little is known about the role of desmosomes in the intestinal epithelium as a knockout of desmoplakin did not affect the structural integrity of the epithelium.

Posttranslational modifications of cell-cell junction proteins affect functions in both tissues. Tyrosine phosphorylation of specific residues of occludin in the intestinal epithelium, for example, reduces the binding affinity to ZO-1 and alters the membrane dynamics of occludin resulting in increased paracellular permeability. Serine/threonine phosphorylation of claudin results in either increased or decreased TJ assembly depending on the claudin type. In the epidermis, phosphorylation of desmosome proteins directly alters desmosome organization and function. For example, phosphorylation of desmoplakin by either PKC- $\alpha$ or GSK3 / PRMT-1 affects desmosome assembly and stability, and association with cytokeratin intermediate filaments, respectively.

Cell migration in the intestine epithelium and epidermis is different, as cells move as an intact epithelium from the crypt and to villus in the intestine during normal cell turnover, whereas cell migration in the epidermis occurs in response to wounding. However, the regulation of migration in both epithelia appears to be mediated by the expression level of cadherins. In the intestine, cadherin mutants increased crypt-villus migration, whereas overexpression slowed migration. In the epidermis, down-regulation of E-cadherin occurs in keratinocytes at the edge of a wound, perhaps to allow cell migration into the wound as well as to trigger cell proliferation.

In summary, the intestinal epithelia and stratified epidermis share similarities in the requirement of cell-cell junctions to maintain homeostasis through regulating the barrier function, cell proliferation and cell migration. Specific cell-cell junctions (TJs) form barriers to the paracellular movement of solutes and pathogens, as both tissues are at the interface with the external environment. Specific cellcell junctions (desmosomes) also appear to be important for maintaining the structural integrity of the tissue, particularly in the presence of mechanical perturbations such as in the epidermis. Cell-cell junctions regulate cell proliferation by sequestering transcription factors at the plasma membrane, and controlling their release to the nucleus where they activate proliferation genes. Thus, it may have been evolutionarily advantageous that cells in different tissues share the same complement of cell-cell junctions that can be adapted to serve diverse functions of different tissues.

\section{ACKNOWLEDGMENTS}

N.C. was supported by a National Science Foundation Graduate Research Fellowship (DGE114747), M.A.G. was supported by a National Institute of Health (NIH) Training Grant (T32CM007276), and work in the Nelson Laboratory was supported by the NIH (R35GM118064-01).

\section{REFERENCES}

${ }^{*}$ Reference is also in this collection.

Abraira VE, Ginty DD. 2013. The sensory neurons of touch. Neuron 79: 618-639.

Acehan D, Petzold C, Gumper I, Sabatini DD, Muller EJ, Cowin P, Stokes DL. 2008. Plakoglobin is required for effective intermediate filament anchorage to desmosomes. J Invest Dermatol 128: 2665-2675.

Al-Nafussi AI, Wright NA. 1982. Cell kinetics in the mouse small intestine during immediate postnatal life. Virchows Arch B Cell Pathol Incl Mol Pathol 40: 51-62.

Al-Sadi R, Khatib K, Guo S, Ye D, Youssef M, Ma T. 2011. Occludin regulates macromolecule flux across the intestinal epithelial tight junction barrier. Am J Physiol Gastrointest Liver Physiol 300: G1054-1064.

Albrecht LV, Zhang L, Shabanowitz J, Purevjav E, Towbin JA, Hunt DF, Green KJ. 2015. GSK3- and PRMT-1-dependent modifications of desmoplakin control desmoplakin-cytoskeleton dynamics. J Cell Biol 208: 597-612.

Albuquerque C, Bakker ER, van Veelen W, Smits R. 2011. Colorectal cancers choosing sides. Biochim Biophys Acta 1816: 219-231.

Amagai M, Klaus-Kovtun V, Stanley JR. 1991. Autoantibodies against a novel epithelial cadherin in pemphigus vulgaris, a disease of cell adhesion. Cell 67: 869-877. 
Amagai M, Ishii K, Hashimoto T, Gamou S, Shimizu N, Nishikawa T. 1995. Conformational epitopes of pemphigus antigens (Dsg1 and Dsg3) are calcium dependent and glycosylation independent. J Invest Dermatol 105: 243247.

Amagai M, Matsuyoshi N, Wang ZH, Andl C, Stanley JR. 2000. Toxin in bullous impetigo and staphylococcal scalded-skin syndrome targets desmoglein 1. Nat Med 6: $1275-1277$.

Amagai M, Yamaguchi T, Hanakawa Y, Nishifuji K, Sugai M, Stanley JR. 2002. Staphylococcal exfoliative toxin B specifically cleaves desmoglein 1. J Invest Dermatol 118: 845 850.

Andreu P, Colnot S, Godard C, Gad S, Chafey P, Niwa-Kawakita M, Laurent-Puig P, Kahn A, Robine S, Perret C, et al. 2005. Crypt-restricted proliferation and commitment to the Paneth cell lineage following Apc loss in the mouse intestine. Development 132: 1443-1451.

Aono S, Hirai Y. 2008. Phosphorylation of claudin-4 is required for tight junction formation in a human keratinocyte cell line. Exp Cell Res 314: 3326-3339.

Balda MS, Garrett MD, Matter K. 2003. The ZO-1-associated Y-box factor ZONAB regulates epithelial cell proliferation and cell density. J Cell Biol 160: 423-432.

Barbara G. 2006. Mucosal barrier defects in irritable bowel syndrome. Who left the door open? Am J Gastroenterol 101: $1295-1298$.

Barker N. 2014. Adult intestinal stem cells: Critical drivers of epithelial homeostasis and regeneration. Nat Rev Mol Cell Biol 15: 19-33.

Bass-Zubek AE, Hobbs RP, Amargo EV, Garcia NJ, Hsieh SN, Chen X, Wahl JKIII, Denning MF, Green KJ. 2008. Plakophilin 2: A critical scaffold for PKC $\alpha$ that regulates intercellular junction assembly. J Cell Biol 181: 605-613.

Basuroy S, Sheth P, Mansbach CM, Rao RK. 2005. Acetaldehyde disrupts tight junctions and adherens junctions in human colonic mucosa: Protection by EGF and Lglutamine. Am J Physiol Gastrointest Liver Physiol 289: G367-375.

Bhat MA, Izaddoost S, Lu Y, Cho KO, Choi KW, Bellen HJ. 1999. Discs Lost, a novel multi-PDZ domain protein, establishes and maintains epithelial polarity. Cell 96: 833-845.

Bhora FY, Dunkin BJ, Batzri S, Aly HM, Bass BL, Sidawy AN, Harmon JW. 1995. Effect of growth factors on cell proliferation and epithelialization in human skin. J Surg Res 59: $236-244$.

Bierkamp C, McLaughlin KJ, Schwarz H, Huber O, Kemler R. 1996. Embryonic heart and skin defects in mice lacking plakoglobin. Dev Biol 180: 780-785.

Bierkamp C, Schwarz H, Huber O, Kemler R. 1999. Desmosomal localization of $\beta$-catenin in the skin of plakoglobin null-mutant mice. Development 126: 371-381.

Bilder D, Schober M, Perrimon N. 2003. Integrated activity of PDZ protein complexes regulates epithelial polarity. Nat Cell Biol 5: 53-58.

Blair SA, Kane SV, Clayburgh DR, Turner JR. 2006. Epithelial myosin light chain kinase expression and activity are upregulated in inflammatory bowel disease. Lab Invest 86: $191-201$.
Bornslaeger EA, Godsel LM, Corcoran CM, Park JK, Hatzfeld M, Kowalczyk AP, Green KJ. 2001. Plakophilin 1 interferes with plakoglobin binding to desmoplakin, yet together with plakoglobin promotes clustering of desmosomal plaque complexes at cell-cell borders. J Cell Sci 114: 727-738.

Boulais N, Misery L. 2008. The epidermis: A sensory tissue. Eur J Dermatol 18: 119-127.

Boyle EC, Brown NF, Finlay BB. 2006. Salmonella enterica serovar Typhimurium effectors SopB, SopE, SopE2 and SipA disrupt tight junction structure and function. Cell Microbiol 8: 1946-1957.

Brandner JM, Kief S, Grund C, Rendl M, Houdek P, Kuhn C, Tschachler E, Franke WW, Moll I. 2002. Organization and formation of the tight junction system in human epidermis and cultured keratinocytes. Eur J Cell Biol 81: 253 263.

Braun KM, Niemann C, Jensen UB, Sundberg JP, SilvaVargas V, Watt FM. 2003. Manipulation of stem cell proliferation and lineage commitment: Visualisation of label-retaining cells in wholemounts of mouse epidermis. Development 130: 5241-5255.

Broussard JA, Getsios S, Green KJ. 2015. Desmosome regulation and signaling in disease. Cell Tissue Res 360: $501-$ 512.

Buchert M, Darido C, Lagerqvist E, Sedello A, Cazevieille C, Buchholz F, Bourgaux JF, Pannequin J, Joubert D, Hollande F. 2009. The symplekin/ZONAB complex inhibits intestinal cell differentiation by the repression of AML1/ Runx1. Gastroenterology 137: 156-164.

Buchert M, Rohde F, Eissmann M, Tebbutt N, Williams B, Tan CW, Owen A, Hirokawa Y, Gnann A, Orend G, et al. 2015. A hypermorphic epithelial $\beta$-catenin mutation facilitates intestinal tumorigenesis in mice in response to compounding WNT-pathway mutations. Dis Model Mech 8: 1361-1373.

* Buckley A, Turner JR. 2017. Cell biology of tight junction barrier regulation and mucosal disease. Cold Spring Harb Perspect Biol doi: 10.1101/cshperspect.a029314.

Buckley CD, Tan J, Anderson KL, Hanein D, Volkmann N, Weis WI, Nelson WJ, Dunn AR. 2014. Cell adhesion. The minimal cadherin-catenin complex binds to actin filaments under force. Science 346: 1-21.

Bukowski M, Wladyka B, Dubin G. 2010. Exfoliative toxins of Staphylococcus aureus. Toxins 2: 1148-1165.

Bullen TF, Forrest S, Campbell F, Dodson AR, Hershman MJ, Pritchard DM, Turner JR, Montrose MH, Watson AJ 2006. Characterization of epithelial cell shedding from human small intestine. Lab Invest 86: 1052-1063.

Cai J, Maitra A, Anders RA, Taketo MM, Pan D. 2015. $\beta$ Catenin destruction complex-independent regulation of Hippo-YAP signaling by APC in intestinal tumorigenesis. Genes Dev 29: 1493-1506.

Canny GO, McCormick BA. 2008. Bacteria in the intestine, helpful residents or enemies from within? Infect Immun 76: $3360-3373$.

Capaldo CT, Koch S, Kwon M, Laur O, Parkos CA, Nusrat A. 2011. Tight function zonula occludens-3 regulates cyclin D1-dependent cell proliferation. Mol Biol Cell 22: 1677 1685. 
M.A. Garcia et al.

Cario E, Gerken G, Podolsky DK. 2004. Toll-like receptor 2 enhances ZO-1-associated intestinal epithelial barrier integrity via protein kinase C. Gastroenterology 127: 224238.

Chan Y, Anton-Lamprecht I, Yu QC, Jackel A, Zabel B, Ernst JP, Fuchs E. 1994. A human keratin 14 "knockout": The absence of K14 leads to severe epidermolysis bullosa simplex and a function for an intermediate filament protein. Genes Dev 8: 2574-2587.

Chandhoke SK, Mooseker MS. 2012. A role for myosin IXb, a motor-RhoGAP chimera, in epithelial wound healing and tight junction regulation. Mol Biol Cell 23: 24682480.

Chavez MG, Buhr CA, Petrie WK, Wandinger-Ness A, Kusewitt DF, Hudson LG. 2012. Differential downregulation of e-cadherin and desmoglein by epidermal growth factor. Dermat Res Pract 2012: 309587.

Chen C, Tao T, Wen C, He WQ, Qiao YN, Gao YQ, Chen X, Wang P, Chen CP, Zhao W, et al. 2014. Myosin light chain kinase (MLCK) regulates cell migration in a myosin regulatory light chain phosphorylation-independent mechanism. J Biol Chem 289: 28478-28488.

Chernyatina AA, Guzenko D, Strelkov SV. 2015. Intermediate filament structure: The bottom-up approach. Curr Opin Cell Biol 32: 65-72.

Chidgey M, Brakebusch C, Gustafsson E, Cruchley A, Hail C, Kirk S, Merritt A, North A, Tselepis C, Hewitt J, et al. 2001. Mice lacking desmocollin 1 show epidermal fragility accompanied by barrier defects and abnormal differentiation. J Cell Biol 155: 821-832.

Cirillo N, AlShwaimi E, McCullough M, Prime SS. 2014. Pemphigus vulgaris autoimmune globulin induces Srcdependent tyrosine-phosphorylation of plakophilin 3 and its detachment from desmoglein 3. Autoimmunity 47: $134-140$.

Clayton E, Doupe DP, Klein AM, Winton DJ, Simons BD, Jones PH. 2007. A single type of progenitor cell maintains normal epidermis. Nature 446: 185-189.

Cooney R, Cummings JR, Pathan S, Beckly J, Geremia A, Hancock L, Guo C, Morris A, Jewell DP. 2009. Association between genetic variants in myosin IXB and Crohn's disease. Inflamm Bowel Dis 15: 1014-1021.

Coulombe PA, Lee CH. 2012. Defining keratin protein function in skin epithelia: Epidermolysis bullosa simplex and its aftermath. J Invest Dermatol 132: 763-775.

Cunningham KE, Turner JR. 2012. Myosin light chain kinase: pulling the strings of epithelial tight junction function. Ann N Y Acad Sci 1258: 34-42.

D'Souza T, Agarwal R, Morin PJ. 2005. Phosphorylation of claudin-3 at threonine 192 by cAMP-dependent protein kinase regulates tight junction barrier function in ovarian cancer cells. J Biol Chem 280: 26233-26240.

Damsky CH, Richa J, Solter D, Knudsen K, Buck CA. 1983. Identification and purification of a cell surface glycoprotein mediating intercellular adhesion in embryonic and adult tissue. Cell 34: 455-466.

Davis MA, Ireton RC, Reynolds AB. 2003. A core function for p120-catenin in cadherin turnover. J Cell Biol 163: $525-534$. de Santa Barbara P, van den Brink Gr Fau-Roberts DJ, Roberts DJ. 2003. Development and differentiation of the intestinal epithelium. Cell Mol Life Sci 60: 1322-1332.

Dehner C, Rotzer V, Waschke J, Spindler V. 2014. A desmoplakin point mutation with enhanced keratin association ameliorates pemphigus vulgaris autoantibody-mediated loss of cell cohesion. Am J Pathol 184: 2528-2536.

Dominguez-Calderon A, Avila-Flores A, Ponce A, LopezBayghen E, Calderon-Salinas JV, Luis Reyes J, ChavezMunguia B, Segovia J, Angulo C, Ramirez L, et al. 2016. $\mathrm{ZO}-2$ silencing induces renal hypertrophy through a cell cycle mechanism and the activation of YAP and the mTOR pathway. Mol Biol Cell 27: 1581-1595.

Dunlop SP, Hebden J, Campbell E, Naesdal J, Olbe L, Perkins AC, Spiller RC. 2006. Abnormal intestinal permeability in subgroups of diarrhea-predominant irritable bowel syndromes. Am J Gastroenterol 101: 1288-1294.

Ebnet K, Suzuki A, Ohno S, Vestweber D. 2004. Junctional adhesion molecules (JAMs): more molecules with dual functions? J Cell Sci 117: 19-29.

Elias BC, Suzuki T, Seth A, Giorgianni F, Kale G, Shen L, Turner JR, Naren A, Desiderio DM, Rao R. 2009. Phosphorylation of Tyr-398 and Tyr-402 in occludin prevents its interaction with ZO-1 and destabilizes its assembly at the tight junctions. J Biol Chem 284: 1559-1569.

Ey B, Eyking A, Gerken G, Podolsky DK, Cario E. 2009. TLR2 mediates gap junctional intercellular communication through connexin-43 in intestinal epithelial barrier injury. J Biol Chem 284: 22332-22343.

Fanning AS, Anderson JM. 2009. Zonula occludens- 1 and -2 are cytosolic scaffolds that regulate the assembly of cellular junctions. Ann N Y Acad Sci 1165: 113-120.

Fanning AS, Van Itallie CM, Anderson JM. 2012. Zonula occludens- 1 and -2 regulate apical cell structure and the zonula adherens cytoskeleton in polarized epithelia. $\mathrm{Mol}$ Biol Cell 23: 577-590.

Fasano A, Baudry B, Pumplin DW, Wasserman SS, Tall BD, Ketley JM, Kaper JB. 1991. Vibrio cholerae produces a second enterotoxin, which affects intestinal tight junctions. Proc Natl Acad Sci 88: 5242-5246.

Fasano A, Fiorentini C, Donelli G, Uzzau S, Kaper JB, Margaretten K, Ding X, Guandalini S, Comstock L, Goldblum SE. 1995. Zonula occludens toxin modulates tight junctions through protein kinase C-dependent actin reorganization, in vitro. J Clin Invest 96: 710-720.

Feighery LM, Cochrane SW, Quinn T, Baird AW, O’Toole D, Owens SE, O’Donoghue D, Mrsny RJ, Brayden DJ. 2008. Myosin light chain kinase inhibition: Correction of increased intestinal epithelial permeability in vitro. Pharm Res 25: 1377-1386.

Findley K, Oh J, Yang J, Conlan S, Deming C, Meyer JA, Schoenfeld D, Nomicos E, Park M, Program NIHISCCS, et al. 2013. Topographic diversity of fungal and bacterial communities in human skin. Nature 498: 367-370.

Fine JD, Bruckner-Tuderman L, Eady RA, Bauer EA, Bauer JW, Has C, Heagerty A, Hintner H, Hovnanian A, Jonkman MF, et al. 2014. Inherited epidermolysis bullosa: Updated recommendations on diagnosis and classification. J Am Acad Dermatology 70: 1103-1126.

Franz CM, Ridley AJ. 2004. p120 catenin associates with microtubules: Inverse relationship between microtubule 
binding and Rho GTPase regulation. J Biol Chem 279: 6588-6594.

Fuchs E. 2016. Epithelial Skin Biology: Three decades of developmental biology, a hundred questions answered and a thousand new ones to address. Curr Top Dev Biol 116: $357-374$.

Furuse M, Sasaki H, Fujimoto K, Tsukita S. 1998. A single gene product, claudin-1 or -2 , reconstitutes tight junction strands and recruits occludin in fibroblasts. J Cell Biol 143: 391-401.

Furuse M, Furuse K, Sasaki H, Tsukita S. 2001. Conversion of zonulae occludentes from tight to leaky strand type by introducing claudin-2 into Madin-Darby canine kidney I cells. J Cell Biol 153: 263-272.

Furuse M, Hata M, Furuse K, Yoshida Y, Haratake A, Sugitani Y, Noda T, Kubo A, Tsukita S. 2002. Claudin-based tight junctions are crucial for the mammalian epidermal barrier: A lesson from claudin-1-deficient mice. J Cell Biol 156: 1099-1111.

Garcia Perez A. 1999. [Epidermolysis bullosa]. An R Acad Nac Med (Madr) 116: 387-413; discussion 413-385.

Garrod D, Chidgey M. 2008. Desmosome structure, composition and function. Biochim Biophys Acta 1778: $572-$ 587.

Gassler N, Rohr C, Schneider A, Kartenbeck J, Bach A, Obermuller N, Otto HF, Autschbach F. 2001. Inflammatory bowel disease is associated with changes of enterocytic junctions. Am J Physiol Gastrointest Liver Physiol 281: G216-228.

Getsios S, Amargo EV, Dusek RL, Ishii K, Sheu L, Godsel LM, Green KJ. 2004. Coordinated expression of desmoglein 1 and desmocollin 1 regulates intercellular adhesion. Differentiation 72: 419-433.

Gonzalez-Mariscal L, Chavez de Ramirez B, Cereijido M. 1985. Tight junction formation in cultured epithelial cells (MDCK). J Membr Biol 86: 113-125.

Gonzalez-Mariscal L, Dominguez-Calderon A, Raya-Sandino A, Ortega-Olvera JM, Vargas-Sierra O, MartinezRevollar G. 2014. Tight junctions and the regulation of gene expression. Semin Cell Dev Biol 36: 213-223.

Goodenough DA, Paul DL. 2009. Gap junctions. Cold Spring Harb Perspect Biol 1: a002576.

Grice EA, Segre JA. 2011. The skin microbiome. Nat Rev Microbiol 9: 244-253.

Guan Y, Watson AJ, Marchiando AM, Bradford E, Shen L, Turner JR, Montrose MH. 2011. Redistribution of the tight junction protein ZO-1 during physiological shedding of mouse intestinal epithelial cells. Am J Physiol Cell Physiol 300: C1404-1414.

Guttman JA, Finlay BB. 2009. Tight junctions as targets of infectious agents. Biochim Biophys Acta 1788: 832-841.

Haines RL, Lane EB. 2012. Keratins and disease at a glance. $J$ Cell Sci 125: 3923-3928.

Hall C, Li S, Li H, Creason V, Wahl JK. 2009. Arrhythmogenic right ventricular cardiomyopathy plakophilin-2 mutations disrupt desmosome assembly and stability. Cell Commun Adhes 16: 15-27.

Harrison OJ, Brasch J, Lasso G, Katsamba PS, Ahlsen G, Honig B, Shapiro L. 2016. Structural basis of adhesive binding by desmocollins and desmogleins. Proc Natl Acad Sci 113: 7160-7165.
Hecht G, Pestic L, Nikcevic G, Koutsouris A, Tripuraneni J, Lorimer DD, Nowak G, Guerriero V Jr, Elson EL, Lanerolle PD. 1996. Expression of the catalytic domain of myosin light chain kinase increases paracellular permeability. Am J Physiol 271: C1678-1684.

Helander HF, Fandriks L. 2014. Surface area of the digestive tract - revisited. Scand J Gastroenterol 49: 681-689.

Hermiston ML, Gordon JI. 1995. In vivo analysis of cadherin function in the mouse intestinal epithelium: Essential roles in adhesion, maintenance of differentiation, and regulation of programmed cell death. J Cell Biol 129: 489-506.

Hermiston ML, Wong MH, Gordon JI. 1996. Forced expression of E-cadherin in the mouse intestinal epithelium slows cell migration and provides evidence for nonautonomous regulation of cell fate in a self-renewing system. Genes Dev 10: 985-996.

Herrmann H, Aebi U. 2004. Intermediate filaments: Molecular structure, assembly mechanism, and integration into functionally distinct intracellular Scaffolds. Annu Rev Biochem 73: 749-789.

Hirai Y, Nose A, Kobayashi S, Takeichi M. 1989. Expression and role of $\mathrm{E}$ - and P-cadherin adhesion molecules in embryonic histogenesis. II. Skin morphogenesis. Development 105: 271-277.

Honda T, Shimizu K, Kawakatsu T, Yasumi M, Shingai T, Fukuhara A, Ozaki-Kuroda K, Irie K, Nakanishi H, Takai Y. 2003. Antagonistic and agonistic effects of an extracellular fragment of nectin on formation of E-cadherinbased cell-cell adhesion. Genes Cells 8: 51-63.

Hong AW, Meng Z, Guan KL. 2016. The Hippo pathway in intestinal regeneration and disease. Nat Rev Gastroenterol Hepatol 13: 324-337.

Hopkins AM, Pineda AA, Winfree LM, Brown GT, Laukoetter MG, Nusrat A. 2007. Organized migration of epithelial cells requires control of adhesion and protrusion through Rho kinase effectors. Am J Physiol Gastrointest Liver Physiol 292: G806-817.

Hsu YC, Li L, Fuchs E. 2014. Emerging interactions between skin stem cells and their niches. Nat Med 20: 847-856.

Huang CH, Hsu CC, Chen CP, Chow SE, Wang JS, Shyu YC, Lu MJ. 2016. Negative pressure induces p120-catenindependent adherens junction disassembly in keratinocytes during wound healing. Biochim Biophys Acta 1863: $2212-2220$.

Hudson LG, McCawley LJ. 1998. Contributions of the epidermal growth factor receptor to keratinocyte motility. Microsc Res Tech 43: 444-455.

Hudson TY, Fontao L, Godsel LM, Choi HJ, Huen AC, Borradori L, Weis WI, Green KJ. 2004. In vitro methods for investigating desmoplakin-intermediate filament interactions and their role in adhesive strength. Methods Cell Biol 78: 757-786.

Huelsken J, Vogel R, Erdmann B, Cotsarelis G, Birchmeier W. 2001. $\beta$-Catenin controls hair follicle morphogenesis and stem cell differentiation in the skin. Cell 105: 533545.

Humar B, Guilford P. 2009. Hereditary diffuse gastric cancer: A manifestation of lost cell polarity. Cancer Sci 100: $1151-1157$. 
M.A. Garcia et al.

Huveneers S, Oldenburg J, Spanjaard E, van der Krogt G, Grigoriev I, Akhmanova A, Rehmann H, de Rooij J. 2012. Vinculin associates with endothelial VE-cadherin junctions to control force-dependent remodeling. J Cell Biol 196: $641-652$.

Ikari A, Matsumoto S, Harada H, Takagi K, Hayashi H, Suzuki Y, Degawa M, Miwa M. 2006. Phosphorylation of paracellin- 1 at Ser 217 by protein kinase A is essential for localization in tight junctions. J Cell Sci 119: 17811789.

Ireton RC, Davis MA, van Hengel J, Mariner DJ, Barnes K, Thoreson MA, Anastasiadis PZ, Matrisian L, Bundy LM, Sealy L, et al. 2002. A novel role for p120 catenin in Ecadherin function. J Cell Biol 159: 3.

Itoh M, Nagafuchi A, Moroi S, Tsukita S. 1997. Involvement of ZO-1 in cadherin-based cell adhesion through its direct binding to $\alpha$ catenin and actin filaments. J Cell Biol 138: $181-192$.

Itoh M, Sasaki H, Furuse M, Ozaki H, Kita T, Tsukita S. 2001. Junctional adhesion molecule (JAM) binds to PAR-3: A possible mechanism for the recruitment of PAR-3 to tight junctions. J Cell Biol 154: 491-497.

Katsuno T, Umeda K, Matsui T, Hata M, Tamura A, Itoh M, Takeuchi K, Fujimori T, Nabeshima Y, Noda T, et al. 2008. Deficiency of zonula occludens-1 causes embryonic lethal phenotype associated with defected yolk sac angiogenesis and apoptosis of embryonic cells. Mol Biol Cell 19: 2465-2475.

Khounlotham M, Kim W, Peatman E, Nava P, Medina-Contreras O, Addis C, Koch S, Fournier B, Nusrat A, Denning TL, et al. 2012. Compromised intestinal epithelial barrier induces adaptive immune compensation that protects from colitis. Immunity 37: 563-573.

Kim NG, Koh E, Chen X, Gumbiner BM. 2011. E-cadherin mediates contact inhibition of proliferation through Hippo signaling-pathway components. Proc Natl Acad Sci 108: 11930-11935.

Kim KY, Namgung R, Lee SM, Kim SC, Eun HS, Park MS, Park KI, Lee C. 2014. Nutritional outcomes in children with epidermolysis bullosa: The experiences of two centers in Korea. Yonsei Med J 55: 264-269.

Kimura TE, Merritt AJ, Garrod DR. 2007. Calcium-independent desmosomes of keratinocytes are hyper-adhesive. J Invest Dermatol 127: 775-781.

King TJ, Gurley KE, Prunty J, Shin JL, Kemp CJ, Lampe PD. 2005. Deficiency in the gap junction protein connexin32 alters p27Kip1 tumor suppression and MAPK activation in a tissue-specific manner. Oncogene 24: 1718-1726.

Kinzler KW, Nilbert MC, Su LK, Vogelstein B, Bryan TM, Levy DB, Smith KJ, Preisinger AC, Hedge P, McKechnie $D$, et al. 1991. Identification of FAP locus genes from chromosome 5q21. Science 253: 661-665.

Kinzler KW, Vogelstein B. 1996. Lessons from hereditary colorectal cancer. Cell 87: 159-170.

Kirschner N, Brandner JM. 2012. Barriers and more: functions of tight junction proteins in the skin. Ann N Y Acad Sci 1257: 158-166.

Knobel M, O'Toole EA, Smith FJ. 2015. Keratins and skin disease. Cell Tissue Res 360: 583-589.
Kobielak A, Fuchs E. 2006. Links between $\alpha$-catenin, NF$\kappa \mathrm{B}$, and squamous cell carcinoma in skin. Proc Natl Acad Sci 103: 2322-2327.

Koch PJ, Mahoney MG, Ishikawa H, Pulkkinen L, Uitto J, Shultz L, Murphy GF, Whitaker-Menezes D, Stanley JR. 1997. Targeted disruption of the pemphigus vulgaris antigen (desmoglein 3) gene in mice causes loss of keratinocyte cell adhesion with a phenotype similar to pemphigus vulgaris. J Cell Biol 137: 1091-1102.

Kohler H, Sakaguchi T, Hurley BP, Kase BA, Reinecker HC, McCormick BA. 2007. Salmonella enterica serovar Typhimurium regulates intercellular junction proteins and facilitates transepithelial neutrophil and bacterial passage. Am J Physiol Gastrointest Liver Physiol 293: G178-187.

Kottke MD, Delva E, Kowalczyk AP. 2006. The desmosome: Cell science lessons from human diseases. J Cell Sci 119: 797-806.

Kowalczyk AP, Bornslaeger EA, Borgwardt JE, Palka HL, Dhaliwal AS, Corcoran CM, Denning MF, Green KJ. 1997. The amino-terminal domain of desmoplakin binds to plakoglobin and clusters desmosomal cadherin-plakoglobin complexes. J Cell Biol 139: 773-784.

Kowalczyk AP, Green KJ. 2013. Structure, function, and regulation of desmosomes. Prog Mol Biol Transl Sci 116: 95118.

Krawczyk WS. 1971. A pattern of epidermal cell migration during wound healing. J Cell Biol 49: 247-263.

Kroger C, Loschke F, Schwarz N, Windoffer R, Leube RE, Magin TM. 2013. Keratins control intercellular adhesion involving PKC- $\alpha$-mediated desmoplakin phosphorylation. J Cell Biol 201: 681-692.

Kulukian A, Fuchs E. 2013. Spindle orientation and epidermal morphogenesis. Philos Trans R Soc Lond B Biol Sci 368: 20130016.

Kuwahara M, Hatoko M, Tada H, Tanaka A. 2001. E-cadherin expression in wound healing of mouse skin. JCutan Pathol 28: 191-199.

Kwong LN, Dove WF. 2009. APC and its modifiers in colon cancer. Adv Exp Med Biol 656: 85-106.

Lameris AL, Huybers S, Kaukinen K, Makela TH, Bindels RJ, Hoenderop JG, Nevalainen PI. 2013. Expression profiling of claudins in the human gastrointestinal tract in health and during inflammatory bowel disease. Scand J Gastroenterol 48: 58-69.

Laukoetter MG, Nava P, Lee WY, Severson EA, Capaldo CT, Babbin BA, Williams IR, Koval M, Peatman E, Campbell JA, et al. 2007. JAM-A regulates permeability and inflammation in the intestine in vivo. J Exp Med 204: 30673076.

le Duc Q, Shi Q, Blonk I, Sonnenberg A, Wang N, Leckband D, de Rooij J. 2010. Vinculin potentiates E-cadherin mechanosensing and is recruited to actin-anchored sites within adherens junctions in a myosin II-dependent manner. J Cell Biol 189: 1107-1115.

Lechler T, Fuchs E. 2005. Asymmetric cell divisions promote stratification and differentiation of mammalian skin. $\mathrm{Na}$ ture 437: 275-280.

Lechuga S, Baranwal S, Ivanov AI. 2015. Actin-interacting protein 1 controls assembly and permeability of intestinal 
epithelial apical junctions. Am J Physiol Gastrointest Liver Physiol 308: G745-756.

Lee MJ, Ran Byun M, Furutani-Seiki M, Hong JH, Jung HS. 2014. YAP and TAZ regulate skin wound healing. J Invest Dermatol 134: 518-525.

Lewis JE, Wahl JKIII, Sass KM, Jensen PJ, Johnson KR, Wheelock MJ. 1997. Cross-talk between adherens junctions and desmosomes depends on plakoglobin. J Cell Biol 136: 919-934.

Liang X, Bhattacharya S, Bajaj G, Guha G, Wang Z, Jang HS, Leid M, Indra AK, Ganguli-Indra G. 2012. Delayed cutaneous wound healing and aberrant expression of hair follicle stem cell markers in mice selectively lacking Ctip2 in epidermis. PLoS ONE 7: e29999.

Ligon LA, Karki S, Tokito M, Holzbaur EL. 2001. Dynein binds to $\beta$-catenin and may tether microtubules at adherens junctions. Nat Cell Biol 3: 913-917.

Lin HC. 2004. Small intestinal bacterial overgrowth: A framework for understanding irritable bowel syndrome. JAMA 292: 852-858.

Lodish HB, Zipursky A, Matsudaira SL, Baltimore P, Darnell D. 2000. Molecular Cell Biology, 4th ed WH. Freeman and Company, NY.

Loschke F, Seltmann K, Bouameur JE, Magin TM. 2015. Regulation of keratin network organization. Curr Opin Cell Biol 32: 56-64.

Lowndes M, Rakshit S, Shafraz O, Borghi N, Harmon RM, Green KJ, Sivasankar S, Nelson WJ. 2014. Different roles of cadherins in the assembly and structural integrity of the desmosome complex. J Cell Sci 127: 2339-2350.

Lu Z, Ding L, Lu Q, Chen YH. 2013. Claudins in intestines: Distribution and functional significance in health and diseases. Tissue Barriers 1: 1-14.

Luissint AC, Nusrat A, Parkos CA. 2014. JAM-related proteins in mucosal homeostasis and inflammation. Semin Immunopathol 36: 211-226.

Madara JL. 1990. Maintenance of the macromolecular barrier at cell extrusion sites in intestinal epithelium: Physiological rearrangements of tight junctions. J Membr Biol 116: $177-184$.

Maes M, Crespo Yanguas S, Willebrords J, Cogliati B, Vinken M. 2015. Connexin and pannexin signaling in gastrointestinal and liver disease. Transl Res 166: 332-343.

Marchiando AM, Shen L, Graham WV, Edelblum KL, Duckworth CA, Guan Y, Montrose MH, Turner JR, Watson AJ. 2011. The epithelial barrier is maintained by in vivo tight junction expansion during pathologic intestinal epithelial shedding. Gastroenterology 140: 1208-1218.

Martin-Padura I, Lostaglio S, Schneemann M, Williams L, Romano M, Fruscella P, Panzeri C, Stoppacciaro A, Ruco L, Villa A, et al. 1998. Junctional adhesion molecule, a novel member of the immunoglobulin superfamily that distributes at intercellular junctions and modulates monocyte transmigration. J Cell Biol 142: 117-127.

Martinez C, Gonzalez-Castro A, Vicario M, Santos J. 2012a. Cellular and molecular basis of intestinal barrier dysfunction in the irritable bowel syndrome. Gut Liver 6: 305315.

Martinez C, Vicario M, Ramos L, Lobo B, Mosquera JL, Alonso C, Sanchez A, Guilarte M, Antolin M, de Torres I, et al. 2012b. The jejunum of diarrhea-predominant irritable bowel syndrome shows molecular alterations in the tight junction signaling pathway that are associated with mucosal pathobiology and clinical manifestations. Am J Gastroenterol 107: 736-746.

Mascre G, Dekoninck S, Drogat B, Youssef KK, Brohee S, Sotiropoulou PA, Simons BD, Blanpain C. 2012. Distinct contribution of stem and progenitor cells to epidermal maintenance. Nature 489: 257-262.

McGrath JA, Mellerio JE. 2010. Ectodermal dysplasia-skin fragility syndrome. Dermatol Clin 28: 125-129.

McGrath JA, McMillan JR, Shemanko CS, Runswick SK, Leigh IM, Lane EB, Garrod DR, Eady RA. 1997. Mutations in the plakophilin 1 gene result in ectodermal dysplasia/skin fragility syndrome. Nat Genet 17: 240-244.

McKoy G, Protonotarios N, Crosby A, Tsatsopoulou A, Anastasakis A, Coonar A, Norman M, Baboonian C, Jeffery S, McKenna WJ. 2000. Identification of a deletion in plakoglobin in arrhythmogenic right ventricular cardiomyopathy with palmoplantar keratoderma and woolly hair (Naxos disease). Lancet 355: 2119-2124.

Meng W, Mushika Y, Ichii T, Takeichi M. 2008. Anchorage of microtubule minus ends to adherens junctions regulates epithelial cell-cell contacts. Cell 135: 948-959.

Merrill BJ, Gat U, DasGupta R, Fuchs E. 2001. Tcf3 and Lef1 regulate lineage differentiation of multipotent stem cells in skin. Genes Dev 15: 1688-1705.

Merritt AJ, Berika MY, Zhai W, Kirk SE, Ji B, Hardman MJ, Garrod DR. 2002. Suprabasal desmoglein 3 expression in the epidermis of transgenic mice results in hyperproliferation and abnormal differentiation. Mol Cell Biol 22: 5846-5858.

Michel D, Arsanto JP, Massey-Harroche D, Beclin C, Wijnholds J, Le Bivic A. 2005. PATJ connects and stabilizes apical and lateral components of tight junctions in human intestinal cells. J Cell Sci 118: 4049-4057.

Monsuur AJ, de Bakker PI, Alizadeh BZ, Zhernakova A, Bevova MR, Strengman E, Franke L, van't Slot R, van Belzen MJ, Lavrijsen IC, et al. 2005. Myosin IXB variant increases the risk of celiac disease and points toward a primary intestinal barrier defect. Nat Genet 37: 13411344.

Monteiro AC, Sumagin R, Rankin CR, Leoni G, Mina MJ, Reiter DM, Stehle T, Dermody TS, Schaefer SA, Hall RA, et al. 2013. JAM-A associates with ZO-2, afadin, and PDZ-GEF1 to activate Rap2c and regulate epithelial barrier function. Mol Biol Cell 24: 2849-2860.

Mosteller RD. 1987. Simplified calculation of body-surface area. N Engl J Med 317: 1098.

Muller SL, Portwich M, Schmidt A, Utepbergenov DI, Huber O, Blasig IE, Krause G. 2005. The tight junction protein occludin and the adherens junction protein $\alpha$-catenin share a common interaction mechanism with ZO-1. J Biol Chem 280: 3747-3756.

Muller FB, Huber M, Kinaciyan T, Hausser I, Schaffrath C, Krieg T, Hohl D, Korge BP, Arin MJ. 2006. A human keratin 10 knockout causes recessive epidermolytic hyperkeratosis. Hum Mol Genet 15: 1133-1141.

Nanney LB, Paulsen S, Davidson MK, Cardwell NL, Whitsitt JS, Davidson JM. 2000. Boosting epidermal growth factor receptor expression by gene gun transfection stimulates epidermal growth in vivo. Wound Repair Regen 8: 117127. 
M.A. Garcia et al.

Nava P, Capaldo CT, Koch S, Kolegraff K, Rankin CR, Farkas AE, Feasel ME, Li L, Addis C, Parkos CA, et al. 2011. JAMA regulates epithelial proliferation through Akt $/ \beta$-catenin signalling. EMBO Rep 12: 314-320.

Nekrasova O, Green KJ. 2013. Desmosome assembly and dynamics. Trends Cell Biol 23: 537-546.

Nekrasova OE, Amargo EV, Smith WO, Chen J, Kreitzer GE, Green KJ. 2011. Desmosomal cadherins utilize distinct kinesins for assembly into desmosomes. J Cell Biol 195: 1185-1203.

Nelson WJ, Nusse R. 2004. Convergence of Wnt, $\beta$-catenin, and cadherin pathways. Science 303: 1483-1487.

Niemann C, Owens DM, Hulsken J, Birchmeier W, Watt FM. 2002. Expression of DeltaNLef1 in mouse epidermis results in differentiation of hair follicles into squamous epidermal cysts and formation of skin tumours. Development 129: $95-109$.

* Niessen C. 2017. Cold Spring Harb Perspect Biol doi 10.1101/cshperpsect.a029207.

Nishisho I, Nakamura Y, Miyoshi Y, Miki Y, Ando H, Horii A, Koyama K, Utsunomiya J, Baba S, Hedge P. 1991. Mutations of chromosome 5q21 genes in FAP and colorectal cancer patients. Science 253: 665-669.

Noah TK, Donahue B, Shroyer NF. 2011. Intestinal development and differentiation. Exp Cell Res 17: 2702-2710.

Nunbhakdi-Craig V, Machleidt T, Ogris E, Bellotto D, White CLIII, Sontag E. 2002. Protein phosphatase 2A associates with and regulates atypical PKC and the epithelial tight junction complex. J Cell Biol 158: 967-978.

Nunez C, Oliver J, Mendoza JL, Gomez-Garcia M, Pinero A, Taxonera C, Diaz-Rubio M, Lopez-Nevot MA, de la Concha EG, Nieto A, et al. 2007. MYO9B polymorphisms in patients with inflammatory bowel disease. Gut 56: 1321 1322.

Ohnemus U, Kohrmeyer K, Houdek P, Rohde H, Wladykowski E, Vidal S, Horstkotte MA, Aepfelbacher M, Kirschner N, Behne MJ, et al. 2008. Regulation of epidermal tight-junctions (TJ) during infection with exfoliative toxin-negative Staphylococcus strains. J Invest Dermatol 128: $906-916$

Oka T, Remue E, Meerschaert K, Vanloo B, Boucherie C, Gfeller D, Bader GD, Sidhu SS, Vandekerckhove J, Gettemans J, et al. 2010. Functional complexes between YAP2 and $\mathrm{ZO}-2$ are $\mathrm{PDZ}$ domain-dependent, and regulate YAP2 nuclear localization and signalling. Biochem $J$ 432: $461-472$.

Orsulic S, Huber O, Aberle H, Arnold S, Kemler R. 1999. Ecadherin binding prevents $\beta$-catenin nuclear localization and $\beta$-catenin/LEF-1-mediated transactivation. J Cell Sci 112: $1237-1245$.

Paladini RD, Takahashi K, Bravo NS, Coulombe PA. 1996. Onset of re-epithelialization after skin injury correlates with a reorganization of keratin filaments in wound edge keratinocytes: defining a potential role for keratin 16. J Cell Biol 132: 381-397.

Pannequin J, Delaunay N, Darido C, Maurice T, Crespy P, Frohman MA, Balda MS, Matter K, Joubert D, Bourgaux JF, et al. 2007. Phosphatidylethanol accumulation promotes intestinal hyperplasia by inducing ZONAB-mediated cell density increase in response to chronic ethanol exposure. Mol Cancer Res 5: 1147-1157.
Perez-Moreno M, Davis MA, Wong E, Pasolli HA, Reynolds AB, Fuchs E. 2006. p120-catenin mediates inflammatory responses in the skin. Cell 124: 631-644.

Peterson LW, Artis D. 2014. Intestinal epithelial cells: Regulators of barrier function and immune homeostasis. Nat Rev Immunol 14: 141-153.

Piche T, Barbara G, Aubert P, Bruley des Varannes S, Dainese R, Nano JL, Cremon C, Stanghellini V, De Giorgio R, Galmiche JP, et al. 2009. Impaired intestinal barrier integrity in the colon of patients with irritable bowel syndrome: Involvement of soluble mediators. Gut 58: 196201.

Pigors M, Schwieger-Briel A, Cosgarea R, Diaconeasa A, Bruckner-Tuderman L, Fleck T, Has C. 2015. Desmoplakin mutations with palmoplantar keratoderma, woolly hair and cardiomyopathy. Acta Derm Venereol 95: 337340.

Pokutta S, Drees F, Takai Y, Nelson WJ, Weis WI. 2002. Biochemical and structural definition of the l-afadinand actin-binding sites of $\alpha$-catenin. J Biol Chem 277: 18868-18874.

Poritz LS, Garver KI, Green C, Fitzpatrick L, Ruggiero F, Koltun WA. 2007. Loss of the tight junction protein ZO-1 in dextran sulfate sodium induced colitis. J Surg Res 140: 12-19.

Radice GP. 1980. The spreading of epithelial cells during wound closure in Xenopus larvae. Dev Biol 76: 26-46.

Raleigh DR, Boe DM, Yu D, Weber CR, Marchiando AM, Bradford EM, Wang Y, Wu L, Schneeberger EE, Shen L, et al. 2011. Occludin S408 phosphorylation regulates tight junction protein interactions and barrier function. J Cell Biol 193: 565-582.

Ramms L, Fabris G, Windoffer R, Schwarz N, Springer R, Zhou C, Lazar J, Stiefel S, Hersch N, Schnakenberg U, et al. 2013. Keratins as the main component for the mechanical integrity of keratinocytes. Proc Natl Acad Sci 110: $18513-18518$.

Rao RK, Basuroy S, Rao VU, Karnaky KJJr, Gupta A. 2002. Tyrosine phosphorylation and dissociation of occludinZO- 1 and E-cadherin- $\beta$-catenin complexes from the cytoskeleton by oxidative stress. Biochem J 368: 471-481.

Reichelt J, Magin TM. 2002. Hyperproliferation, induction of c-Myc and 14-3-3sigma, but no cell fragility in keratin10-null mice. J Cell Sci 115: 2639-2650.

Repertinger SK, Campagnaro E, Fuhrman J, El-Abaseri T, Yuspa SH, Hansen LA. 2004. EGFR enhances early healing after cutaneous incisional wounding. J Invest Dermatol 123: 982-989.

Rodgers LS, Beam MT, Anderson JM, Fanning AS. 2013. Epithelial barrier assembly requires coordinated activity of multiple domains of the tight junction protein $\mathrm{ZO}-1 . J$ Cell Sci 126: 1565-1575.

Rodgers LS, Fanning AS. 2011. Regulation of epithelial permeability by the actin cytoskeleton. Cytoskeleton (Hoboken) 68: 653-660.

Rugg EL, McLean WH, Lane EB, Pitera R, McMillan JR, Dopping-Hepenstal PJ, Navsaria HA, Leigh IM, Eady RA. 1994. A functional "knockout" of human keratin 14. Genes Dev 8: 2563-2573.

Safferling K, Sutterlin T, Westphal K, Ernst C, Breuhahn K, James M, Jager D, Halama N, Grabe N. 2013. Wound 
healing revised: A novel reepithelialization mechanism revealed by in vitro and in silico models. J Cell Biol 203: 691-709.

Saitou M, Fujimoto K, Doi Y, Itoh M, Fujimoto T, Furuse M, Takano H, Noda T, Tsukita S. 1998. Occludin-deficient embryonic stem cells can differentiate into polarized epithelial cells bearing tight junctions. J Cell Biol 141: 397408.

Saitou M, Furuse M, Sasaki H, Schulzke JD, Fromm M, Takano H, Noda T, Tsukita S. 2000. Complex phenotype of mice lacking occludin, a component of tight junction strands. Mol Biol Cell 11: 4131-4142.

Samak G, Gangwar R, Crosby LM, Desai LP, Wilhelm K, Waters CM, Rao R. 2014. Cyclic stretch disrupts apical junctional complexes in Caco-2 cell monolayers by a JNK-2-, c-Src-, and MLCK-dependent mechanism. Am J Physiol Gastrointest Liver Physiol 306: G947-958.

Sansom OJ, Reed KR, Hayes AJ, Ireland H, Brinkmann H, Newton IP, Batlle E, Simon-Assmann P, Clevers H, Nathke IS, et al. 2004. Loss of Apc in vivo immediately perturbs Wnt signaling, differentiation, and migration. Genes Dev 18: 1385-1390.

Sapone A, Lammers KM, Casolaro V, Cammarota M, Giuliano MT, De Rosa M, Stefanile R, Mazzarella G, Tolone C, Russo MI, et al. 2011. Divergence of gut permeability and mucosal immune gene expression in two gluten-associated conditions: Celiac disease and gluten sensitivity. BMC Med 9: 23.

Schlegelmilch K, Mohseni M, Kirak O, Pruszak J, Rodriguez JR, Zhou D, Kreger BT, Vasioukhin V, Avruch J, Brummelkamp TR, et al. 2011. Yap1 acts downstream of $\alpha$ catenin to control epidermal proliferation. Cell 144: $782-795$.

Schmidt GH, Winton DJ, Ponder BA. 1988. Development of the pattern of cell renewal in the crypt-villus unit of chimaeric mouse small intestine. Development 103: 785790.

Schmidt E, Kelly SM, van der Walle CF. 2007. Tight junction modulation and biochemical characterisation of the zonula occludens toxin C-and N-termini. FEBS Lett 581: 2974-2980.

Sedhom MA, Pichery M, Murdoch JR, Foligne B, Ortega N, Normand S, Mertz K, Sanmugalingam D, Brault L, Grandjean T, et al. 2013. Neutralisation of the interleukin-33/ST2 pathway ameliorates experimental colitis through enhancement of mucosal healing in mice. Gut 62: $1714-1723$.

Sekiguchi M, Futei Y, Fujii Y, Iwasaki T, Nishikawa T, Amagai M. 2001. Dominant autoimmune epitopes recognized by pemphigus antibodies map to the $\mathrm{N}$-terminal adhesive region of desmogleins. J Immunol 167: 5439-5448.

Seltmann K, Fritsch AW, Kas JA, Magin TM. 2013. Keratins significantly contribute to cell stiffness and impact invasive behavior. Proc Natl Acad Sci 110: 18507-18512.

Sendroy JJr, Cecchini LP. 1954. Determination of human body surface area from height and weight. J Appl Physiol 7: $1-12$.

Severson EA, Lee WY, Capaldo CT, Nusrat A, Parkos CA. 2009. Junctional adhesion molecule A interacts with Afadin and PDZ-GEF2 to activate Rap1A, regulate beta1 integrin levels, and enhance cell migration. Mol Biol Cell 20: 1916-1925.
Shahbazi MN, Megias D, Epifano C, Akhmanova A, Gundersen GG, Fuchs E, Perez-Moreno M. 2013. CLASP2 interacts with $\mathrm{p} 120$-catenin and governs microtubule dynamics at adherens junctions. J Cell Biol 203: $1043-$ 1061.

Shapiro L, Weis WI. 2009. Structure and biochemistry of cadherins and catenins. Cold Spring Harb Perspect Biol 1: a003053.

Shen L, Black ED, Witkowski ED, Lencer WI, Guerriero V, Schneeberger EE, Turner JR. 2006. Myosin light chain phosphorylation regulates barrier function by remodeling tight junction structure. J Cell Sci 119: 2095-2106.

Shi VY, Leo M, Hassoun L, Chahal DS, Maibach HI, Sivamani RK. 2015. Role of sebaceous glands in inflammatory dermatoses. J Am Acad Dermatol 73: 856-863.

Shibata H, Toyama K, Shioya H, Ito M, Hirota M, Hasegawa S, Matsumoto H, Takano H, Akiyama T, Toyoshima K, et al. 1997. Rapid colorectal adenoma formation initiated by conditional targeting of the Apc gene. Science 278: $120-123$.

Shimizu A, Ishiko A, Ota T, Tsunoda K, Amagai M, Nishikawa T. 2004. IgG binds to desmoglein 3 in desmosomes and causes a desmosomal split without keratin retraction in a pemphigus mouse model. J Invest Dermatol 122: $1145-1153$.

Silvis MR, Kreger BT, Lien WH, Klezovitch O, Rudakova GM, Camargo FD, Lantz DM, Seykora JT, Vasioukhin V. 2011. $\alpha$-catenin is a tumor suppressor that controls cell accumulation by regulating the localization and activity of the transcriptional coactivator Yap1. Sci Signal 4: ra33.

Singh MS, Broadgate S, Mathur R, Holt R, Halford S, MacLaren RE. 2016. Hypotrichosis and juvenile macular dystrophy caused by CDH3 mutation: A candidate disease for retinal gene therapy. Sci Rep 6: 23674.

Sourisseau T, Georgiadis A, Tsapara A, Ali RR, Pestell R, Matter K, Balda MS. 2006. Regulation of PCNA and cyclin D1 expression and epithelial morphogenesis by the ZO-1-regulated transcription factor ZONAB/DbpA. Mol Cell Biol 26: 2387-2398.

Spadaro D, Tapia R, Jond L, Sudol M, Fanning AS, Citi S. 2014. ZO proteins redundantly regulate the transcription factor DbpA/ZONAB. J Biol Chem 289: 22500-22511.

Su L, Shen L, Clayburgh DR, Nalle SC, Sullivan EA, Meddings JB, Abraham C, Turner JR. 2009. Targeted epithelial tight junction dysfunction causes immune activation and contributes to development of experimental colitis. Gastroenterology 136: 551-563.

Sumigray KD, Lechler T. 2012. Desmoplakin controls microvilli length but not cell adhesion or keratin organization in the intestinal epithelium. Mol Biol Cell 23: 792799.

Suzuki T, Elias BC, Seth A, Shen L, Turner JR, Giorgianni F, Desiderio D, Guntaka R, Rao R. 2009. PKC $\eta$ regulates occludin phosphorylation and epithelial tight junction integrity. Proc Natl Acad Sci 106: 61-66.

Szakal DN, Gyorffy H, Arato A, Cseh A, Molnar K, Papp M, Dezsofi A, Veres G. 2010. Mucosal expression of claudins 2, 3 and 4 in proximal and distal part of duodenum in children with coeliac disease. Virchows Arch 456: 245250 . 
M.A. Garcia et al.

Tachibana K, Nakanishi H, Mandai K, Ozaki K, Ikeda W, Yamamoto Y, Nagafuchi A, Tsukita S, Takai Y. 2000. Two cell adhesion molecules, nectin and cadherin, interact through their cytoplasmic domain-associated proteins. J Cell Biol 150: 1161-1176.

Takai Y, Nakanishi H. 2003. Nectin and afadin: Novel organizers of intercellular junctions. J Cell Sci 116: 17-27.

Takeichi M. 2014. Dynamic contacts: Rearranging adherens junctions to drive epithelial remodelling. Nat Rev Mol Cell Biol 15: 397-410.

Takigawa H, Nakagawa H, Kuzukawa M, Mori H, Imokawa G. 2005. Deficient production of hexadecenoic acid in the skin is associated in part with the vulnerability of atopic dermatitis patients to colonization by Staphylococcus aureus. Dermatology 211: 240-248.

Tanaka-Okamoto M, Hori K, Ishizaki H, Itoh Y, Onishi S, Yonemura S, Takai Y, Miyoshi J. 2011. Involvement of afadin in barrier function and homeostasis of mouse intestinal epithelia. J Cell Sci 124: 2231-2240.

Tariq H, Bella J, Jowitt TA, Holmes DF, Rouhi M, Nie Z, Baldock C, Garrod D, Tabernero L. 2015. Cadherin flexibility provides a key difference between desmosomes and adherens junctions. Proc Natl Acad Sci 112: 5395-5400.

Thomas WA, Boscher C, Chu YS, Cuvelier D, Martinez-Rico C, Seddiki R, Heysch J, Ladoux B, Thiery JP, Mege RM, et al. 2013. $\alpha$-Catenin and vinculin cooperate to promote high E-cadherin-based adhesion strength. J Biol Chem 288: 4957-4969.

Tinkle CL, Lechler T, Pasolli HA, Fuchs E. 2004. Conditional targeting of E-cadherin in skin: Insights into hyperproliferative and degenerative responses. Proc Natl Acad Sci 101: 552-557.

Tinkle CL, Pasolli HA, Stokes N, Fuchs E. 2008. New insights into cadherin function in epidermal sheet formation and maintenance of tissue integrity. Proc Natl Acad Sci 105: 15405-15410.

Toivola DM, Boor P, Alam C, Strnad P. 2015. Keratins in health and disease. Curr Opin Cell Biol 32: 73-81.

Troy TC, Turksen K. 2007. The targeted overexpression of a Claudin mutant in the epidermis of transgenic mice elicits striking epidermal and hair follicle abnormalities. $\mathrm{Mol}$ Biotechnol 36: 166-174.

Tsapara A, Matter K, Balda MS. 2006. The heat-shock protein Apg-2 binds to the tight junction protein $\mathrm{ZO}-1$ and regulates transcriptional activity of ZONAB. Mol Biol Cell 17: $1322-1330$.

Tunggal JA, Helfrich I, Schmitz A, Schwarz H, Gunzel D, Fromm M, Kemler R, Krieg T, Niessen CM. 2005. E-cadherin is essential for in vivo epidermal barrier function by regulating tight junctions. EMBO J 24: 1146-1156.

Turner JR, Rill BK, Carlson SL, Carnes D, Kerner R, Mrsny RJ, Madara JL. 1997. Physiological regulation of epithelial tight junctions is associated with myosin light-chain phosphorylation. Am J Physiol 273: C1378-1385.

Umeda K, Matsui K, Nakayama M, Furuse K, Sasaki H, Furuse M, Tsukita S. 2004. Establishment and characterization of cultured epithelial cells lacking expression of ZO-1. J Biol Chem 279: 44785-44794.

Umeda K, Ikenouchi J, Katahira-Tayama S, Furuse K, Sasaki $\mathrm{H}$, Nakayama M, Matsui T, Tsukita S, Furuse M, Tsukita S. 2006. ZO-1 and ZO-2 independently determine where claudins are polymerized in tight-junction strand formation. Cell 126: 741-754.

Usui ML, Underwood RA, Mansbridge JN, Muffley LA, Carter WG, Olerud JE. 2005. Morphological evidence for the role of suprabasal keratinocytes in wound reepithelialization. Wound Repair Regen 13: 468-479.

Vahidnezhad H, Youssefian L, Saeidian AH, Mozafari N, Barzegar M, Sotoudeh S, Daneshpazhooh M, Isaian A, Zeinali S, Uitto J. 2016. KRT5 and KRT14 mutations in epidermolysis bullosa simplex with phenotypic heterogeneity, and evidence of semidominant inheritance in a multiplex family. J Invest Dermatol 136: 1897-1901.

van Bodegraven AA, Curley CR, Hunt KA, Monsuur AJ, Linskens RK, Onnie CM, Crusius JB, Annese V, Latiano A, Silverberg MS, et al. 2006. Genetic variation in myosin IXB is associated with ulcerative colitis. Gastroenterology 131: $1768-1774$.

van der Flier LG, Clevers H. 2009. Stem cells, self-renewal, and differentiation in the intestinal epithelium. Annu Rev Physiol 71: 241-260.

Van Itallie CM, Anderson JM. 2006. Claudins and epithelial paracellular transport. Annu Rev Physiol 68: 403-429.

Van Itallie CM, Anderson JM. 2014. Architecture of tight junctions and principles of molecular composition. Semin Cell Dev Biol 36: 157-165.

Van Itallie CM, Fanning AS, Bridges A, Anderson JM. 2009. ZO-1 stabilizes the tight junction solute barrier through coupling to the perijunctional cytoskeleton. Mol Biol Cell 20: $3930-3940$.

Vasioukhin V, Bauer C, Degenstein L, Wise B, Fuchs E. 2001a. Hyperproliferation and defects in epithelial polarity upon conditional ablation of $\alpha$-catenin in skin. Cell 104: 605-617.

Vasioukhin V, Bowers E, Bauer C, Degenstein L, Fuchs E. 2001b. Desmoplakin is essential in epidermal sheet formation. Nat Cell Biol 3: 1076-1085.

Vetrano S, Rescigno M, Cera MR, Correale C, Rumio C, Doni A, Fantini M, Sturm A, Borroni E, Repici A, et al. 2008. Unique role of junctional adhesion molecule-a in maintaining mucosal homeostasis in inflammatory bowel disease. Gastroenterology 135: 173-184.

Vijayaraj P, Kroger C, Reuter U, Windoffer R, Leube RE, Magin TM. 2009. Keratins regulate protein biosynthesis through localization of GLUT1 and -3 upstream of AMP kinase and Raptor. J Cell Biol 187: 175-184.

Vogelstein B, Papadopoulos N, Velculescu VE, Zhou S, Diaz LAJr, Kinzler KW. 2013. Cancer genome landscapes. Science 339: 1546-1558.

Wang H, Li ZY, Liu Y, Persson J, Beyer I, Moller T, Koyuncu D, Drescher MR, Strauss R, Zhang XB, et al. 2011. Desmoglein 2 is a receptor for adenovirus serotypes 3, 7, 11 and 14. Nat Med 17: 96-104.

Wang H, Yumul R, Cao H, Ran L, Fan X, Richter M, Epstein F, Gralow J, Zubieta C, Fender P, et al. 2013. Structural and functional studies on the interaction of adenovirus fiber knobs and desmoglein 2. J Virol 87: 11346-11362.

Wang H, Ducournau C, Saydaminova K, Richter M, Yumul R, Ho M, Carter D, Zubieta C, Fender P, Lieber A. 2015. Intracellular signaling and desmoglein 2 shedding triggered by human adenoviruses Ad3, Ad14, and Ad14P1. J Virol 89: 10841-10859. 
Watt FM. 2014. Mammalian skin cell biology: at the interface between laboratory and clinic. Science 346: 937-940.

Weis WI, Nelson WJ. 2006. Re-solving the cadherin-catenin-actin conundrum. J Biol Chem 281: 35593-35597.

Whitehead J, Vignjevic D, Futterer C, Beaurepaire E, Robine S, Farge E. 2008. Mechanical factors activate $\beta$-catenindependent oncogene expression in APC mouse colon. HFSP J 2: 286-294.

Willecke K, Eiberger J, Degen J, Eckardt D, Romualdi A, Guldenagel M, Deutsch U, Sohl G. 2002. Structural and functional diversity of connexin genes in the mouse and human genome. Biol Chem 383: 725-737.

Williams JM, Duckworth CA, Burkitt MD, Watson AJ, Campbell BJ, Pritchard DM. 2015. Epithelial cell shedding and barrier function: A matter of life and death at the small intestinal villus tip. Vet Pathol 52: 445-455.

Woodley DT, Chen JD, Kim JP, Sarret Y, Iwasaki T, Kim YH, O’Keefe EJ. 1993. Re-epithelialization. Human keratinocyte locomotion. Dermatol Clin 11: 641-646.

Xu J, Kausalya PJ, Phua DC, Ali SM, Hossain Z, Hunziker W. 2008. Early embryonic lethality of mice lacking ZO-2, but Not ZO-3, reveals critical and nonredundant roles for individual zonula occludens proteins in mammalian development. Mol Cell Biol 28: 1669-1678.

Yamamoto T, Harada N, Kano K, Taya S, Canaani E, Matsuura Y, Mizoguchi A, Ide C, Kaibuchi K. 1997. The Ras target AF-6 interacts with ZO- 1 and serves as a peripheral component of tight junctions in epithelial cells. J Cell Biol 139: $785-795$.

Yamamoto Y, Aoyama Y, Shu E, Tsunoda K, Amagai M Kitajima Y. 2007. Anti-desmoglein 3 (Dsg3) monoclonal antibodies deplete desmosomes of Dsg3 and differ in their Dsg3-depleting activities related to pathogenicity. J Biol Chem 282: 17866-17876.

Yano T, Matsui T, Tamura A, Uji M, Tsukita S. 2013. The association of microtubules with tight junctions is promoted by cingulin phosphorylation by AMPK. J Cell Biol 203: 605-614.

Yao M, Qiu W, Liu R, Efremov AK, Cong P, Seddiki R, Payre M, Lim CT, Ladoux B, Mege RM, et al. 2014. Force-de- pendent conformational switch of $\alpha$-catenin controls vinculin binding. Nat Commun 31: 1-11.

Yap AS, Niessen CM, Gumbiner BM. 1998. The juxtamembrane region of the cadherin cytoplasmic tail supports lateral clustering, adhesive strengthening, and interaction with p120ctn. J Cell Biol 141: 779-789.

Yin T, Getsios S, Caldelari R, Godsel LM, Kowalczyk AP, Muller EJ, Green KJ. 2005. Mechanisms of plakoglobindependent adhesion: Desmosome-specific functions in assembly and regulation by epidermal growth factor receptor. J Biol Chem 280: 40355-40363.

Yonemura S, Wada Y, Watanabe T, Nagafuchi A, Shibata M. 2010. $\alpha$-Catenin as a tension transducer that induces adherens junction development. Nat Cell Biol 12: 533542.

Youssef G, Gerner L, Naeem AS, Ralph O, Ono M, O’Neill CA, O'Shaughnessy RF. 2013. Rab3Gap1 mediates exocytosis of Claudin-1 and tight junction formation during epidermal barrier acquisition. Dev Biol 380: 274-285.

Yu FX, Guan KL. 2013. The Hippo pathway: Regulators and regulations. Genes Dev 27: 355-371.

Yumul R, Richter M, Lu ZZ, Saydaminova K, Wang H, Wang CH, Carter D, Lieber A. 2016. Epithelial junction opener improves oncolytic adenovirus therapy in mouse tumor models. Hum Gene Ther 27: 325-337.

Zhu AJ, Watt FM. 1996. Expression of a dominant negative cadherin mutant inhibits proliferation and stimulates terminal differentiation of human epidermal keratinocytes. J Cell Sci 109: 3013-3023.

Zhu AJ, Watt FM. 1999. $\beta$-catenin signalling modulates proliferative potential of human epidermal keratinocytes independently of intercellular adhesion. Development 126: $2285-2298$.

Zihni C, Mills C, Matter K, Balda MS. 2016. Tight junctions: From simple barriers to multifunctional molecular gates. Nat Rev Mol Cell Biol 17: 564-580.

Zolotarevsky Y, Hecht G, Koutsouris A, Gonzalez DE, Quan C, Tom J, Mrsny RJ, Turner JR. 2002. A membrane-permeant peptide that inhibits MLC kinase restores barrier function in in vitro models of intestinal disease. Gastroenterology 123: 163-172. 


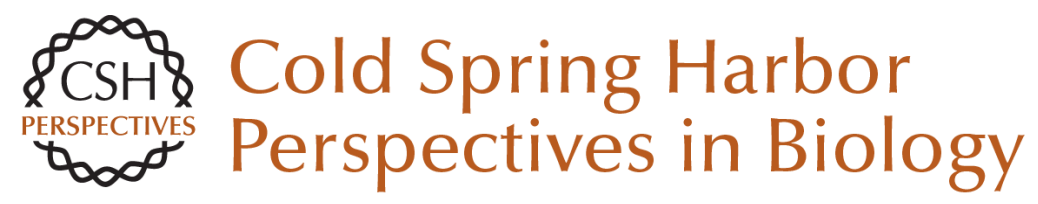

\section{Cell-Cell Junctions Organize Structural and Signaling Networks}

Miguel A. Garcia, W. James Nelson and Natalie Chavez

Cold Spring Harb Perspect Biol 2018; doi: 10.1101/cshperspect.a029181 originally published online June 9, 2017

\section{Subject Collection Cell-Cell Junctions}

Vascular Endothelial (VE)-Cadherin, Endothelial Adherens Junctions, and Vascular Disease Maria Grazia Lampugnani, Elisabetta Dejana and Costanza Giampietro

Adherens Junctions and Desmosomes Coordinate Mechanics and Signaling to Orchestrate Tissue Morphogenesis and Function: An Evolutionary Perspective Matthias Rübsam, Joshua A. Broussard, Sara A. Wickström, et al.

Cell-Cell Contact and Receptor Tyrosine Kinase Signaling Christine Chiasson-MacKenzie and Andrea I. McClatchey

Hold Me, but Not Too Tight---Endothelial Cell-Cell Junctions in Angiogenesis Anna Szymborska and Holger Gerhardt

\section{Connexins and Disease} Mario Delmar, Dale W. Laird, Christian C. Naus, et al.

\section{Cell Junctions in Hippo Signaling}

Ruchan Karaman and Georg Halder

Loss of E-Cadherin-Dependent Cell-Cell Adhesion and the Development and Progression of Cancer Heather C. Bruner and Patrick W.B. Derksen
Signaling by Small GTPases at Cell-Cell Junctions: Protein Interactions Building Control and Networks Vania Braga

Making Connections: Guidance Cues and Receptors at Nonneural Cell-Cell Junctions Ian V. Beamish, Lindsay Hinck and Timothy E. Kennedy

The Cadherin Superfamily in Neural Circuit Assembly James $D$. Jontes

Mechanosensing and Mechanotransduction at Cell-Cell Junctions Alpha S. Yap, Kinga Duszyc and Virgile Viasnoff

Beyond Cell-Cell Adhesion: Sensational

Cadherins for Hearing and Balance Avinash Jaiganesh, Yoshie Narui, Raul Araya-Secchi, et al.

Cell-Cell Junctions Organize Structural and Signaling Networks Miguel A. Garcia, W. James Nelson and Natalie Chavez

Cell Biology of Tight Junction Barrier Regulation and Mucosal Disease Aaron Buckley and Jerrold R. Turner

For additional articles in this collection, see http://cshperspectives.cshlp.org/cgi/collection/

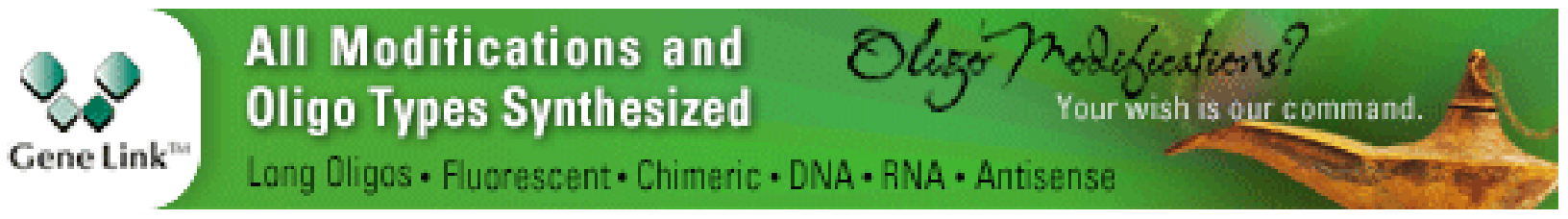


Desmosomes and Intermediate Filaments: Their Consequences for Tissue Mechanics Mechthild Hatzfeld, René Keil and Thomas $M$. Magin
Integration of Cadherin Adhesion and

Cytoskeleton at Adherens Junctions

René Marc Mège and Noboru Ishiyama

For additional articles in this collection, see http://cshperspectives.cshlp.org/cgi/collection/

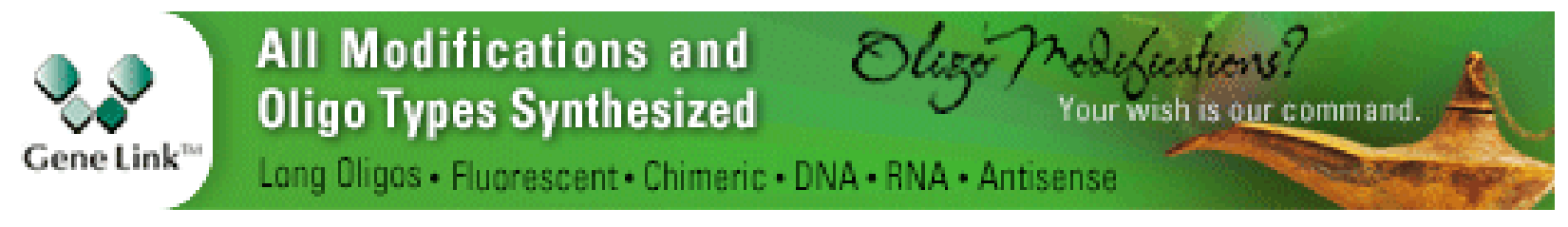

Copyright @ 2018 Cold Spring Harbor Laboratory Press; all rights reserved 